\title{
Contribution of intracrine oestrogens to the aetiology of endometriosis
}

\author{
Carla A Piccinato', Helena Malvezzi', Douglas A Gibson² and Philippa T K Saunders² \\ ${ }^{1}$ Hospital Israelita Albert Einstein, São Paulo, São Paulo, Brazil \\ 2MRC Centre for Inflammation Research, The University of Edinburgh, Edinburgh, UK \\ Correspondence should be addressed to C A Piccinato: cpiccinato@uwalumni.com
}

This paper is part of a thematic section on Sulfation Pathways. The guest editors for this section were Jonathan Wolf Mueller and Paul Foster.

\begin{abstract}
Endometriosis is an incurable hormone-dependent inflammatory disease that causes chronic pelvic pain and infertility characterized by implantation and growth of endometrial tissue outside the uterine cavity. Symptoms have a major impact on the quality of life of patients resulting in socioeconomic, physical and psychological burdens. Although the immune system and environmental factors may play a role in the aetiology of endometriosis, oestrogen dependency is still considered a hallmark of the disorder. The impact of oestrogens such as oestrone and particularly, oestradiol, on the endometrium or endometriotic lesions may be mediated by steroids originating from ovarian steroidogenesis or local intra-tissue production (intracrinology) dependent upon the expression and activity of enzymes that regulate oestrogen biosynthesis and metabolism. Two key pathways have been implicated: while there is contradictory data on the participation of the aromatase enzyme (encoded by CYP19A1), there is increasing evidence that the steroid sulphatase pathway plays a role in both the aetiology and pathology of endometriosis. In this review, we consider the evidence related to the pathways leading to oestrogen accumulation in endometriotic lesions and how this might inform the development of new therapeutic strategies to treat endometriosis without causing the undesirable side effects of current regimes that suppress ovarian hormone production.
\end{abstract}

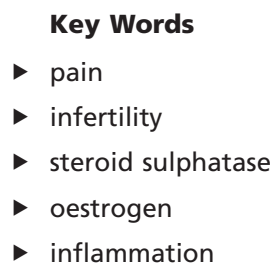

Journal of Molecular Endocrinology (2018) 61, T253-T270

\section{Introduction}

Prevalence, characteristics and socioeconomic impact of endometriosis

Endometriosis is characterized by implantation and growth of endometrial tissue outside the uterine cavity (Agarwal et al. 2005). It is often associated with clinical symptoms that impair quality of life, including dysmenorrhoea, dyspareunia, acyclic pelvic pain, infertility and alterations of intestinal and urinary habits (Kyama et al. 2003, Bellelis

http://jme.endocrinology-journals.org https://doi.org/10.1530/JME-17-0297

(c) 2018 Society for Endocrinology Published by Bioscientifica Ltd. Printed in Great Britain et al. 2014, Vercellini et al. 2014). Endometriosis lesions can form at different sites within the pelvis such as superficial peritoneal lesions, ovarian endometriomas (cysts) and may also be detected as deep-infiltrating lesions that can compromise other organs such as rectum and bladder (Chapron et al. 2006). The location of the lesion, its invasiveness and the presence and severity of adhesions in the peritoneal cavity were all taken into account by the American Society for Reproductive Medicine when 
they proposed a characterization of the disorder into four stages (I-minimal, II-mild, III-moderate and IV-severe) (American Society for Reproductive Medicine 1997).

Endometriosis is a common disorder that is believed to affect $6-10 \%$ of women of reproductive age estimated to be 176 million women worldwide (Bulletti et al. 2010). An increased prevalence is commonly found in women with infertility, pelvic pain or both, with values ranging from 30 to 50\% (Eskenazi \& Warner 1997, Giudice \& Kao 2004). Due to the severity of the symptoms experienced by some women with endometriosis, it has a high socioeconomic cost resulting in women being unable to work or care for their families and high associated health care costs in part because of the number of hospital admissions (Nnoaham et al. 2011, Fuldeore et al. 2015). For all these reasons, it has been argued that endometriosis should receive far greater attention and funding than it does currently (Signorile \& Baldi 2010, Nnoaham et al. 2011, Culley et al. 2013, De Graaff et al. 2013, 2015, Vercellini et al. 2014, Fuldeore et al. 2015, Zubrzycka et al. 2015).

\section{Genomics, genetics and lack of predictive biomarkers}

Definitive diagnosis of endometriosis is based on the identification of lesions by visual inspection at the time of surgery. Importantly, there is poor correlation between extent of disease and severity of symptoms, which underlies our poor understanding of disease aetiology (Gopalakrishnan Radhika et al. 2016). Currently, there are no reliable, non-invasive biomarker tests which, in part, explains why diagnosis is often delayed for many years (Gupta et al. 2016, Nisenblat et al. 2016). Surgically confirmed disease occurs six- to nine-fold more commonly in first-degree relatives of affected women than in those of unaffected women (Kennedy 1999, Hompes \& Mijatovic 2007), which has led to the classification of endometriosis as a polygenic, heritable disease and prompted the search for genetic biomarkers. A recent meta-analysis of 11 genome-wide association case-control data sets, involving 17,045 endometriosis cases identified five new genetic loci (SNPs) significantly associated with endometriosis risk implicating genes involved in sex steroid hormone pathways that included FN1, CCDC170, ESR1, SYNE1 and FSHB genes (Sapkota et al. 2017). In addition, genomic analysis of eutopic endometrium has reported differential expression of key genes between samples from women with endometriosis and those without (Aghajanova et al. 2009, Zelenko et al. 2012) that are associated with alterations in functional activities (Nikoo et al. 2014).
These findings offer potential for development of new diagnostic approaches based on genetic or tissue profiling (Tamaresis et al. 2014) with the former prompting the formation of large multinational consortia to test findings using larger datasets (Montgomery et al. 2008).

\section{Current therapies}

Current treatments for endometriosis-associated pelvic pain and/or infertility include both surgical and medical approaches. Due to the high costs and risks associated with surgery, it is frequently considered as a second choice with priority given to medical therapy for mild/ moderate disease. For severe disease, particularly, that involves obstructive urinary/intestinal lesions or large endometrioma, surgery is the first choice (Halpern et al. 2015). Surgical removal of lesions can offer some relief from pain and may improve fertility; however, recurrence of symptoms is reported in up to $75 \%$ of women within 5 years of surgery (Guo 2009). Although the cause(s) of endometriosis remain incompletely understood, there is intense research activity involving observations on primary samples and fluids (blood, peritoneal), in vitro studies using cells isolated from patients and controls, as well as testing in a range of preclinical animal models (see recent review by Greaves et al. 2017) all directed at gaining knowledge that might be translated into more effective ways to prevent recurrence or treat symptoms.

It is widely accepted that inflammatory processes can contribute to the development of endometriosis and associated pain symptoms (Králíčková \& Vetvicka 2015). However, currently, it is the hormone (oestrogen) dependence of the disease that has been most effectively targeted by medical therapy. The first-line treatments of hormonal therapies work by suppressing ovarian function: this includes use of GnRH agonists and birth control pills, whereas others utilise inhibitors of the aromatase enzyme, which is essential for biosynthesis of oestrogens by ovarian follicles (Lindsay et al. 2015, Vercellini et al. 2016). Some reports suggest these treatments may result in pain reduction up to $80 \%$ of endometriosis patients, especially when a combination of drugs is used (Platteeuw \& D'Hooghe 2014, Zhao et al. 2015). However, gonadotropin-releasing hormone analogue or aromatase inhibitor (AI) therapies are associated with negative side effects that mimic a premature menopause (including hot flashes symptoms) while birth control pills are not ideal for women wanting to get pregnant. Also, a proportion of patients either fail to respond or relapse after relatively short period of time. In the search for new therapies, steroid 
sulphatase (STS) inhibitors originally developed as a new drug for oestrogen-dependent breast cancers are being considered (Purohit et al. 2008). The suggestion that STS inhibitors could be repurposed for treating endometriosis has been supported by reports using murine models of endometriosis where a $40 \%$ reduction in lesions size was reported following oral treatment with oestradiol3-O-sulfamate, a readily absorbed and transformed STS inhibitor (Colette et al. 2011). In the following review, we consider the evidence that endometriosis is an oestrogendependent disorder, that local oestrogens generated in situ are important regulators of disease and how this might inform new therapies avoiding undesirable side effects.

\section{Endometriosis: an oestrogen-dependent disorder}

\section{Sources of endometrial-acting oestrogens}

During a woman's reproductive years, the primary site of synthesis of the bioactive oestrogens, oestrone (E1) and oestradiol (E2) are the ovaries, particularly the ovarian follicles. Oestrogen biosynthesis by ovarian follicular cell types has been extensively reviewed (Lessey et al. 1989, Huhtinen et al. 2012a). In brief, it begins with the transport of cellular cholesterol from the cytosol to mitochondria matrix by steroidogenic acute regulatory protein (STAR). Inside the mitochondria, cholesterol is converted into pregnenolone by cholesterol side-chain cleavage enzyme (P450scc, encoded by CYP11A1). Pregnenolone can then be transformed into progesterone by 3 $\beta$-hydroxysteroid dehydrogenase type 2 (HSD3B2) (Attar et al. 2009). Pregnenolone can also be converted into 17- $\beta$ hydroxypregnenolone, DHEA and then androstenedione by steroid $17 \alpha$-monooxygenase $(17,20$-lyase, P450c17, encoded by CYP17A1), which in turn can be reduced to testosterone primarily by 17- $\beta$-hydroxysteroid dehydrogenase 3 (HSD17B3), mainly expressed in testis, and AKR1C3 which is expressed in endometrium and endometriosis (Catalano et al. 2011, Sinreih et al. 2015). Androstenedione and testosterone are substrates of the aromatase complex (P450arom, encoded by CYP19A1), which are converted to E1 and E2, respectively. Finally, HSD17B1 can convert E1 into E2, considered to be the more potent bioactive form of oestrogen: both E1 and E2 can bind and activate oestrogen receptors.

There is also evidence that oestrogens can be synthesized in extra-ovarian sites including the endometrium, endometriosis lesions (discussed below) and adipose tissue. According to the concept of intracrinology (Labrie et al. 2000), extra-ovarian tissues that express the enzymes that regulate oestrogen biosynthesis have the capacity to utilize blood borne precursors including DHEA and the sulphated oestrogens (E1S and E2S). One potential extra-ovarian site for E2 biosynthesis is adipose tissue (Kim et al. 2014). Adipose cells express oestrogen-synthesizing enzymes (Nelson \& Bulun 2001), and in vitro production of oestrogens has been described (Ghosh et al. 2013). It remains unknown whether the oestrogen produced by adipose tissues has any impact on the amount of circulating E1/E2 or if this has an impact on the endometrium or endometriosis lesion development. However, as women with endometriosis have a significantly lower body mass index than women without disease (Vitonis et al. 2010), it is less likely that adipose-derived oestrogens have a prominent role in endometriosis development.

Notably, endometrial tissue homogenates are reported to contain two to five times greater concentrations of E2 compared to the serum levels (Huhtinen et al. 2012b) consistent with a potential role for intracrine synthesis. One possible source of $\mathrm{E} 2$ is the reduction of $\mathrm{E} 1$ present in the blood bathing the tissue to $\mathrm{E} 2$ by action of the reductive enzyme HSD17B type 1 that has been consistently detected in the endometrium and differs between ectopic and eutopic tissue (Huhtinen et al. 2012b, Delvoux et al. 2014). Although aromatase expression has not been detected in stromal cells isolated from healthy endometrium during the proliferative phase, it is reported to be upregulated in response to a decidualization stimulus (progesterone and cAMP), suggesting that this enzyme may play a role in intracrine production of E2 required for regulation of immune and other cells in preparation for embryo implantation (Gibson et al. 2013, 2015, 2016). Clearly, further studies are needed to fully understand the local mechanisms of oestrogen biosynthesis and metabolism in the healthy endometrium, taking into account reports of an impaired response to progesterone in women with endometriosis (termed 'progesterone resistance', Burney et al. 2007).

\section{Expression of oestrogen receptors and impact of oestrogen on normal endometrium}

In humans, two isoforms of oestrogen receptor have been identified: $\mathrm{ER} \alpha$ (NR3A1) and ER $\beta$ (NR3A2). These are encoded by two separate genes, ESR 1 and ESR2, respectively, located on the human chromosomes 6q25.1 (ESR1) and 14q23.3 (ESR2) (Nilsson et al. 2001). The messenger RNAs for both receptors are present in the human endometrium, 
and detailed immunohistochemical analysis has revealed that expression of the two receptors are distinct with respect to cell type with changes in the epithelial cells being regulated according to stage of the cycle (Critchley et al. 2001). Studies in mouse models have identified a key role for ER $\alpha$ in both stromal-epithelial interactions and the regulation of epithelial cell proliferation (Hewitt et al. 2017). Notably, ER $\beta$ but not $E R \alpha$ is present in the vascular endothelium of the human and non-human primate endometrium and appears to regulate the E2 responsiveness of these cells consistent with oestrogen regulation of angiogenesis (Critchley et al. 2001, Greaves et al. 2013). The impact of $\mathrm{E} 2$ on diverse immune cell populations may also be regulated by ER $\beta$ as the receptor has been detected in the nuclei of uterine natural killer (uNK) (Henderson et al. 2003) and mast cells (De Leo et al. 2017). Notably, recent studies have demonstrated that uNK cells treated with E2 release the chemokine CCL2, which promotes endometrial endothelial cells to form angiogenesis networks (Gibson et al. 2015). This will, in turn, provide a potential mechanism by which local E2 might have an impact on cell types that play a key role in establishment of endometriosis lesions.

\section{Detection of steroids in endometrium and endometriosis lesions}

Traditionally, oestrogens have been measured using either gas chromatography/mass spectrometry or immunoassay. The development of highly sensitive liquid chromatography coupled with tandem mass spectrometry (LC-MS-MS) as a technique for steroid detection offered an approach for more precise, accurate detection of E2 (Harwood \& Handelsman 2009). Using LC-MS-MS, it has been possible to measure $\mathrm{E} 2$ and $\mathrm{E} 1$ in endometrial tissue homogenates demonstrating that they vary according to menstrual cycle phase and that they do not parallel serum levels (Huhtinen et al. 2012b). In endometriosis lesions, E2 was the most abundant oestrogen and concentrations were independent of cycle phase in peritoneal and deepinfiltrating lesions (Huhtinen et al. 2012b). Notably, alterations in expression of many of the enzymes involved in biosynthesis and metabolism of oestrogens in endometriosis and endometrial cancer has been reviewed previously (Rižner 2009, 2013, Huhtinen et al. 2012a) with parallels to reports of local oestrogen biosynthesis in endometrial cancer (as reviewed by Rižner et al. 2017) with a pro-oestrogenic environment reported to drive cell proliferation in the latter.

\section{Expression of oestrogen receptors in endometriosis lesions}

Differences in expression of ESR1 and ESR2 in endometriotic tissue have been reported by several groups (reviewed by Rižner 2009, Huhtinen et al. 2012a). The Bulun group has investigated the expression of oestrogen receptors in endometriosis lesions (reviewed in Bulun et al. 2012), reporting overexpression of ERß and identifying changes in promoter methylation as a possible mechanism (Xue et al. 2007). Immunohistochemical analysis has localized ERß to both immune cells and nerves in lesions recovered from women and animal models (Greaves et al. 2015). Remarkably, as shown in studies using in vitro models, E2 can have an impact on nerves, vascular cells and immune cells, and it has been suggested they could be regulated via ERß. It has also been postulated that $\mathrm{E} 2$ may have an impact on neuroangiogenesis (Greaves et al. 2014) and contribute to pain mechanisms (Liang \& Yao 2016). Following the development of ERß-selective agonists and antagonists (reviewed in Burris et al. 2013), these observations that ERß was overexpressed in endometriosis lesions prompted investigations in preclinical models to see if they might offer a novel therapeutic option. Although some results from preclinical tests appeared promising (reviewed by Harris 2007) to date, there has been limited transparency about the results of clinical trials (Guo et al. 2009) and searches do not suggest they are still in active development for treatment of this condition.

\section{Local (intracrine) biosynthesis of oestrogens in endometriosis}

Until recently, it has been widely accepted that the pathway most likely to influence local concentrations of $\mathrm{E} 1 / \mathrm{E} 2$ in endometriotic lesions is the one that culminates in transformation of androgens into oestrogens by the aromatase enzyme complex (P450arom). However, a second pathway that depends on the ability of STS to convert conjugated steroids found at high concentration in blood such as sulphated oestrogens oestradiol sulphate (E2S) and oestrone sulphate (E1S) into bioactive E2 or E1, respectively, is also likely to be playing a role. In endometriotic lesions, oestrogens can be formed by the following three main pathways: (i) de novo from cholesterol; (ii) from androstenedione or testosterone via the aromatase pathway or (iii) from E1S via the sulphatase pathway. Evidence for all these pathways operating in the context of endometriosis is reviewed below. 


\section{Pathways utilizing cholesterol to generate androgens or progestins}

Table 1 summarizes articles that study the main enzymes that utilize cholesterol to generate androgens or progestins.

\section{Steroidogenic acute regulatory protein}

Cholesterol is a ubiquitous steroid precursor, and STAR regulates the transport of cholesterol from the outer membrane to the inner membrane of mitochondria where it can be metabolized into pregnenolone by P450scc (Soffientini \& Graham 2016). STAR mRNA expression was found to be higher in ectopic endometrium compared to eutopic and control endometrium (Tsai et al. 2001, Attar etal.2009, Huhtinen etal.2014). Moreover, between eutopic and control endometrium, STAR was described as more pronounced in eutopic endometrium of endometriosis patients (Tsai et al. 2001, Sun et al. 2003), showing a correlation with the severity of the disease (Tian et al. 2009). Utsunomiya et al. (2008) went further, suggesting that alterations in the amount of the transcription factor steroidogenic factor 1 (SF-1), which promotes expression of both STAR and P450arom, was regulated by higher expression of stimulatory factor type 2 (USF2) that was uniquely expressed in ectopic stromal endometrium cells. Thus, dysregulation in stromal endometriotic cells may be causing enhanced expression of SF-1, which in turn upregulates STAR mRNA expression (Shen et al. 2013). Prostaglandin E2 (PGE2), present in high concentrations in inflammatory diseases such as endometriosis, also stimulates STAR expression in human endometriotic stromal cells (Tsai et al. 2001, Hsu et al. 2008, Attar et al. 2009), which could also increase the concentration of mitochondrial cholesterol and favour increased oestrogen biosynthesis. Conversely, a lack of difference in STAR expression between eutopic endometrium from women with vs without endometriosis was reported in one study (Aghajanova et al. 2009) suggesting further investigations are required.

\section{Cholesterol side chain cleavage (CYP11A1)}

The cholesterol side chain cleavage enzyme (encoded by CYP11A1, also referred to as CYP450scc) that is responsible for converting cholesterol into pregnenolone is located exclusively within the inner mitochondria membrane (Van 2013). An in vivo experiment by Attar et al. described higher CYP450scc mRNA levels in ectopic lesions compared with control endometrium (Attar et al. 2009). Conversely, in other studies, no differences in CYP11A1 mRNA expression between eutopic control endometrium and ectopic endometrium were recorded (Tsai et al. 2001, Aghajanova et al. 2009). Interestingly, treatment of endometrial epithelial and stromal cell cultures from

Table 1 mRNA expression of enzymes from pathways utilizing cholesterol to generate androgens or progestagens.

\begin{tabular}{|c|c|c|c|c|}
\hline Enzyme & Patient number & Sample number & Differential expression & Reference \\
\hline \multirow[t]{5}{*}{ STAR } & $E=29 ; C=13$ & $\mathrm{EE}=7 ; \mathrm{CE}=6$ & $\mathrm{EE}=\mathrm{CE}$ & Aghajanova et al. (2009) \\
\hline & $E=30 ; C=16$ & $E L=13 ; O E=17 ; C E=16$ & $\uparrow \mathrm{EL} / \mathrm{CE}$ & Attar et al. (2009) \\
\hline & $E=23 ; C=15$ & $E L=23 ; E E=23 ; C E=15$ & $\begin{array}{l}\uparrow \mathrm{EL} ; \mathrm{EE} / \mathrm{CE} \\
\uparrow \mathrm{EL} / \mathrm{EE}\end{array}$ & Shen et al. (2013) \\
\hline & $E=30 ; C=25$ & $E L=30 ; C E=25$ & $\uparrow \mathrm{EL} / \mathrm{CE}$ & Tian et al. (2009) \\
\hline & $E=35 ; C=15$ & $\begin{array}{l}E L=25 ; O E=10 ; A D M=4 ; \\
C E L=10 ; C E=1\end{array}$ & $\uparrow \mathrm{EL} ; \mathrm{OE} / \mathrm{ADM} ; \mathrm{CL} ; \mathrm{CE}$ & Tsai et al. (2001) \\
\hline \multirow[t]{5}{*}{ CYP11A1 } & $E=29 ; C=13$ & $\mathrm{EE}=7 ; \mathrm{CE}=6$ & $\mathrm{EE}=\mathrm{CE}$ & Aghajanova et al. (2009) \\
\hline & $E=30 ; C=16$ & $E L=13 ; O E=17 ; C E=16$ & $\uparrow \mathrm{EL} / \mathrm{CE}$ & Attar et al. (2009) \\
\hline & $E=38 ; C=31$ & $E L=16 ; E E=16 ; C E=31$ & $\uparrow \mathrm{EL} ; \mathrm{EE} / \mathrm{CE}$ & Fouquet et al. (2016) \\
\hline & $E=60 ; C=16$ & $E L=23 ; O E=18 ; E E=18 ; C E=16$ & $\uparrow \mathrm{OE} / \mathrm{CE}$ & Huhtinen et al. (2014) \\
\hline & $E=35 ; C=15$ & $\begin{array}{l}E L=25 ; O E=10 ; A D M=4 ; \\
\quad C L=10 ; C E=1\end{array}$ & $\uparrow E L ; O E=A D M ; C L ; C E$ & Tsai et al. (2001) \\
\hline \multirow[t]{4}{*}{ HSD3B2 } & $E=29 ; C=13$ & $\mathrm{EE}=7 ; \mathrm{CE}=6$ & $\mathrm{EE}=\mathrm{CE}$ & Aghajanova et al. (2009) \\
\hline & $E=30 ; C=16$ & $E L=13 ; O E=17 ; C E=16$ & $\uparrow \mathrm{EL} / \mathrm{CE}$ & Attar et al. (2009) \\
\hline & $E=60 ; C=16$ & $E L=23 ; O E=18 ; E E=18 ; C E=16$ & $\uparrow \mathrm{EL} ; \mathrm{OE} / \mathrm{CE}$ & Huhtinen et al. (2014) \\
\hline & $E=35 ; C=15$ & $\begin{array}{l}E L=25 ; O E=10 ; A D M=4 ; \\
C L=10 ; C E=1\end{array}$ & $\uparrow E L ; O E=A D M ; C L ; C E$ & Tsai et al. (2001) \\
\hline \multirow[t]{3}{*}{ P450c17 } & $E=30 ; C=16$ & $E L=13 ; O E=17 ; C E=16$ & $\uparrow \mathrm{EL} / \mathrm{CE}$ & Attar et al. (2009) \\
\hline & $E=38 ; C=31$ & $E L=16 ; E E=16 ; C E=31$ & $\uparrow E L ; E E / C E$ & Fouquet et al. (2016) \\
\hline & $E=60 ; C=16$ & $E L=23 ; O E=18 ; E E=18 ; C E=16$ & $\uparrow \mathrm{OE} / \mathrm{CE}$ & Huhtinen et al. (2014) \\
\hline
\end{tabular}

$\mathrm{ADM}$, adenomyosis myometrium; $\mathrm{C}$, control patients - control patients are considered all women without endometriosis; $\mathrm{CE}$, control endometrium; $\mathrm{CEL}$, control endometrium from leiomyoma patients; $E$, endometriosis patients; $E E$, eutopic endometrium from endometriosis; EL, endometriosis lesionextraovarian; $\mathrm{OE}$, ovarian endometriosis. 
women with and without endometriosis with PGE2 promoted increased levels of CYP11A1 gene expression (Attar et al. 2009, Fouquet et al. 2016), indicating that inflammatory mediators may also influence the expression of this steroidogenic enzyme.

\section{HSD3B2}

The steroidogenic enzyme HSD3B catalyzes the conversion of pregnenolone into progesterone, DHEA into androstenedione and also 17-hydroxypregnenolone into 17-hydroxyprogesterone. 3 $\beta$-HSD (isoform not specified) are expressed in the ovary (Simard et al. 2005) and endometrium (Casey et al. 1994). The published studies evaluated difference in HSD3B2 expression in the endometriosis patients, Tsai et al. and Aghajanova et al. observed no difference in amount of HSD3B2 expression between normal and ectopic endometrium (Tsai et al. 2001, Aghajanova et al. 2009). In contrast, other studies, higher HSD3B2 mRNA concentrations and enzyme activity were detected in ectopic vs eutopic endometrium (Attar et al. 2009, Huhtinen et al. 2014), suggesting a greater intralesion synthesis of steroidogenesis precursors. To further investigate the regulation of HSD3B2 in endometriosis patients, Urata and colleagues designed an experiment to test the effect of PGE2 and interleukin 4 (IL-4), a cytokine known to be present in high levels in women with endometriosis, on stromal cells from endometrioma, showing that both factors enhanced HSD3B2 mRNA expression in a dose-dependent manner (Urata et al. 2013). Similar findings were described by Attar et al. (2009). Nevertheless, the treatment with IL-4 or PGE2 did not produce an effect on HSD3B2 mRNA expression in stromal cells from eutopic endometrium (Urata et al. 2013).

\section{CYP17A1}

Steroid $17 \alpha$-monooxygenase catalyzes the conversion of progestins to androstenedione by firstly converting progesterone and pregnenolone into 17-hydroxyprogesterone and 17-hydroxypregnenolone, respectively. Afterwards, 17-hydroxyprogesterone is further metabolized by P450c17 into androstenedione. Alternatively, 17-hydroxypregnenolone can either be converted into DHEA or 17-hydroxyprogesterone by P450c17 and HSD3B2, respectively. HSD3B2 catalyzes the conversion of DHEA into androstenedione (Simard et al. 2005, Tsuchiya et al. 2005a). Increasing the expression of P450c17 in HEK 293 cells enhances the formation of DHEA and diminishes 17-hydroxypregnenolone showing the importance of this enzyme in complex steroidogenesis pathways (Soucy \& Van 2000). In endometriosis, P450c17 mRNA expression was found to be higher in ectopic lesions (ovarian endometrioma and/or peritoneal tissue) compared with control endometrium (Borghese et al. 2008, Attar et al. 2009, Huhtinen et al. 2014). The same higher expression was observed in epithelial and stromal endometriotic cells (Attar et al. 2009). As with CYP11A1 and HSD3B2 enzymes, the expression of P450c17 in stromal endometriotic cell cultures was also enhanced by treatment with PGE2 highlighting the potential for pro-inflammatory factors to have an impact on multiple enzymes within the steroidogenic pathways to regulate steroid synthesis in endometriosis (Tsai et al. 2001, Attar et al. 2009). Moreover, P450c17 expression in epithelial endometriotic cells was also enhanced by human chorionic gonadotropin and insulin like-3, both factors known to be involved in cell growth, differentiation, invasion and vascularization, all pathophysiological mechanism implicated in the development of the disease (Fouquet et al. 2016). On the contrary, others have reported no difference in expression of P450c17 between eutopic endometrium from women with and without endometriosis (Aghajanova et al. 2009). The CYP17 gene, located on chromosome 10q24.3, has been intensively studies to find disease-associated polymorphisms (Soucy $\&$ Van 2000): some have been correlated with variations in steroid hormone levels, menstrual factors and risk of endometrial and breast cancers (Devore \& Scott 2012). However, although several studies have tried to relate polymorphisms in CYP17 with susceptibility to endometriosis (Supplementary Table 1, see section on supplementary data given at the end of this article), there is as yet no clear evidence for a correlation.

\section{Pathways utilizing androgens to generate oestrogens}

Table 2 summarizes articles that study the main enzymes, which utilize androgens to generate oestrogens.

\section{AKR1C3}

Aldo-keto reductase family 1 member C3 (AKR1C3; also known as $17 \beta$ hydroxysteroid dehydrogenase type 5 ) is a steroidogenic enzyme with diverse substrate specificities and activities. AKR1C3 may contribute to a prooestrogenic state in endometriosis as studies investigating the enzyme kinetics of the recombinant human protein suggest AKR1C3 can promote (i) direct reduction of E1 
Table 2 mRNA expression of enzymes from pathways utilizing androgens to generate oestrogens.

\begin{tabular}{|c|c|c|c|c|}
\hline Enzyme & Patient number & Sample number & Differential expression & Reference \\
\hline \multirow[t]{4}{*}{ AKR1C3 } & $E=24 ; C=10$ & $\mathrm{OE}=24 ; \mathrm{CE}=10$ & $\uparrow \mathrm{OE} / \mathrm{CE}$ & Šmuc et al. (2009) \\
\hline & $E=31 ; C=37$ & $\mathrm{OE}=31 ; \mathrm{CE}=28 ; \mathrm{CEM}=9$ & $\uparrow \mathrm{OE} / \mathrm{CE} ; \mathrm{CEM}$ & Hevir et al. (2011) \\
\hline & $E=60 ; C=16$ & $\mathrm{EL}=4 ; \mathrm{OE}=4 ; \mathrm{EE}=4 ; \mathrm{CE}=4$ & $\mathrm{EL}=\mathrm{OE}=\mathrm{EE}=\mathrm{CE}$ & Huhtinen et al. $(2012 b) * * *$ \\
\hline & $E=45 ; C=29$ & $\mathrm{EL}=21 ; \mathrm{EE}=45 ; \mathrm{CE}=29$ & $\begin{array}{l}\uparrow \mathrm{EL} / \mathrm{CE}^{*} \\
\mathrm{EL}=\mathrm{EE}\end{array}$ & Rakhila et al. (2013) \\
\hline \multirow[t]{13}{*}{ CYP19 } & $E=14 ; C=48$ & $E L=14 ; E E=14 ; C E=48$ & $\mathrm{CE}^{\wedge}$ & Dassen et al. (2007) \\
\hline & $E=30 ; C=16$ & $\mathrm{EL}=13 ; \mathrm{OE}=17 ; \mathrm{CE}=16$ & $\uparrow \mathrm{EL} / \# \mathrm{CE}$ & Attar et al. (2009) \\
\hline & $E=29 ; C=13$ & $\mathrm{EE}=7 ; \mathrm{CE}=6$ & $\uparrow \mathrm{EE} / \mathrm{CE}$ & Aghajanova et al. (2009) \\
\hline & $E=14 ; C=15$ & $\mathrm{EL}=14 ; \mathrm{EE}=12 ; \mathrm{CE}=8 ; \mathrm{CFE}=7$ & $\begin{array}{l}\uparrow \mathrm{EE} / \# \mathrm{CE} ; \mathrm{CFE} \\
\uparrow \mathrm{EL} / \mathrm{EE}\end{array}$ & Bukulmez et al. (2008b) \\
\hline & $E=38 ; C=31$ & $E L=16 ; E E=16 ; C E=31$ & $\uparrow \mathrm{EL}$ and $\mathrm{EE} /{ }^{\#} \mathrm{CE}$ & Fouquet et al. (2016) \\
\hline & $E=60 ; C=16$ & $\mathrm{EL}=23 ; \mathrm{OE}=18 ; \mathrm{EE}=18 ; \mathrm{CE}=15$ & $\uparrow \mathrm{OE} /{ }^{*} \mathrm{CE}$ & Huhtinen et al. $(2012 b)^{* * *}$ \\
\hline & $E=10 ; C=20$ & $\mathrm{EL}=10 ; \mathrm{EE}=10 ; \mathrm{ADM}=10 ; \mathrm{CCE}=10$ & $\uparrow \mathrm{EL} ; \mathrm{EE} ; \mathrm{ADM} / \mathrm{CCE}$ & Kitawaki et al. (1997) \\
\hline & $E=42 ; C=21$ & $\mathrm{EE}=42 ; \mathrm{CCE}=21$ & $\uparrow \mathrm{EE} /{ }^{\#} \mathrm{CCE}$ & Kitawaki et al. (1999) \\
\hline & $E=15 ; C=19$ & $\mathrm{EL}=15 ; \mathrm{EE}=15 ; \mathrm{CE}=19$ & $\uparrow \mathrm{EL} / \mathrm{EE} ; \mathrm{CE}$ & Morsch et al. (2009) \\
\hline & $E=17 ; C=7$ & $\mathrm{EL}=17 ; \mathrm{EE}=11 ; \mathrm{CE}=7 ; \mathrm{ENP}=7$ & $\uparrow \mathrm{EL} ; \mathrm{EE} /{ }^{\#} \mathrm{CE} ; \mathrm{ENP}$ & Noble et al. (1996b) \\
\hline & $E=23 ; C=15$ & $\mathrm{EL}=23 ; \mathrm{EE}=23 ; \mathrm{CE}=15$ & $\begin{array}{l}\uparrow \mathrm{EL} ; \mathrm{EE} / \# \mathrm{CE} \\
\uparrow \mathrm{EL} / \mathrm{EE}\end{array}$ & Shen et al. (2013) \\
\hline & $E=16 ; C=9$ & $O C E=16 ; C O C=9$ & $\uparrow \mathrm{OE} / \# \mathrm{COC}$ & Smuc et al. (2007) \\
\hline & $E=24 ; C=10$ & $O E=24 ; C E=10$ & $\uparrow \mathrm{OE} / \mathrm{CE}$ & Šmuc et al. (2009) \\
\hline
\end{tabular}

\#Absence of mRNA expression; ' $m R$ RA expression near detection limit; *only when comparing patients in the proliferative phase; ${ }^{* *}$ when comparing patients in the proliferative vs secretory phase. It was considered significant all mRNA expression with $P<0.005$.

ADM, adenomyosis myometrium; C, control patients - control patients are considered all women without endometriosis; $C C E$, cervical carcinoma endometrium; $\mathrm{CE}$, control endometrium; $\mathrm{CEM}$, control endometrium with myoma; $\mathrm{CFE}$, control with fibrosis endometrium; $\mathrm{COC}$, control ovarian cyst; $\mathrm{E}$, endometriosis patients; $\mathrm{EE}$, eutopic endometrium from endometriosis women; EL, endometriosis lesion-extraovarian; ENP, endometriosis normal peritonium; OCE, ovarian endometriotic cyst from patients with endometriosis; $\mathrm{OE}$, ovarian endometriomas.

to the more potent E2 and (ii) reduction of progesterone to less potent metabolite $20 \alpha$-hydroxyprogesterone (Penning et al. 2000). In hormone-dependent cancers, AKR1C3 is reported to promote activation of oestrogens by catalysing the reduction of E1 to E2, which promotes proliferation of MCF7 breast cancer cells (Penning \& Byrns 2009). In addition, AKR1C3 catalyses reduction of androstenedione to testosterone, which may impact on androgen-oestrogen balance in the endometrium.

AKR1C3 has been detected in the human endometrium with peak expression reported in the early secretory phase of the menstrual cycle (Catalano et al. 2011). Expression of AKR1C3 mRNA measured by qPCR in endometriosis has been reported in tissue from peritoneal, ovarian and deepinfiltrating endometriosis, but no significant changes in expression were reported across menstrual cycle phase or between different tissue types (Huhtinen et al. $2012 b$ ). Hevir et al. reported AKR1C3 mRNA is modestly increased in ovarian endometriomas compared to normal endometrium (Hevir et al. 2011) while the same group subsequently found that expression of AKR1C3 protein was unchanged between endometrioma and control endometrium (Sinreih et al. 2015). Recent reports suggest AKR1C3 is increased in primary ectopic endometrial cells from ovarian endometriomas compared to cells isolated from control endometria, although the cell types isolated from these tissues were not stated in the study (Kim et al. 2017). Immunohistochemistry analysis of AKR1C3 in endometrioma tissues demonstrated expression mainly detected in epithelial and to a lesser extent in stromal cells (Hevir et al. 2011). Analysis of cell lines derived from peritoneal endometriosis tissues suggest AKR1C3 mRNA is increased in peritoneal endometriosis stromal cell lines (22-B) compared to control stromal cell lines (HIESC) (Sinreih et al. 2015). In contrast, AKR1C3 mRNA expression was decreased in $12-\mathrm{Z}$ epithelial cells derived from peritoneal endometriosis compared to control HIEEC epithelial cell line (Sinreih et al. 2015). Rakhila et al. investigated AKR1C3 mRNA expression in women with stage I-II endometriosis (American Fertility Society classification system (Practice \& Medicine 2012) and reported increased AKR1C3 in ectopic endometrium compared to control endometrium (Rakhila et al. 2013). Notably, when samples were stratified according to menstrual cycle stage, a significant increase in AKR1C3 was only detected in samples from the proliferative phase of the cycle highlighting the complexity of interpreting AKR1C3 expression studies (Rakhila et al. 2013). Taken together, these studies suggest endometrial AKR1C3 may contribute to an altered steroid environment within 
endometriosis lesions but further studies are required to establish if this affects growth/persistence of endometriosis lesions. Notably, AKR1C3 also catalyses reduction of isoprenyl aldehydes as well as retinaldehydes with high catalytic efficiency as compared to other substrates (Endo et al. 2011, Ruiz et al. 2011). In addition, AKR1C3 can function as a prostaglandin F2 $\alpha$ (PGF2 $\alpha$ ) synthase and PGF2 $\alpha$ concentrations are elevated in the peritoneal fluid from endometriosis patients compared to healthy women (Sinreih et al. 2015). AKR1C3 may therefore have diverse effects and influence multiple signalling pathways in endometriosis.

\section{Aromatase (CYP19)}

Aromatase (P450arom), encoded by CYP19A1, is a member of the cytochrome P450 family. This enzyme plays a key role in oestrogen biosynthesis by catalysing the aromatization of the androgens, androstenedione and testosterone into E2 and E1, respectively. The CYP19A1 gene is located in chromosome 15q21.2 and the association of polymorphism and endometriosis risk in different ethnicities has been explored; however, the results are inconsistent and inconclusive, even within the same population (Supplementary Table 2) (Yi et al. 2016). There have also been differing results reported related to the presence or absence of P450arom in endometrium and ectopic lesions with reports of atypical expression in patients with endometriosis (Bulun et al. 2004, Ferrero et al. 2014, Blakemore \& Naftolin 2016). Several studies report that protein and mRNA expression of P450arom can be detected in ectopic and/or eutopic endometrium of endometriosis patients, but not in normal endometrium (Noble et al. 1996a, Kitawaki et al. 1997, 1999, Tsai et al. 2001, Dassen et al. 2007, Hudelist et al. 2007, Smuc et al. 2007, Bukulmez et al. 2008a, Attar et al. 2009, Šmuc et al. 2009, Morsch et al. 2009, Huhtinen et al. 2012b, 2014, Shen et al. 2013, Suganuma et al. 2014, Fouquet et al. 2016) although this is disputed by others who failed to detect expression in either ectopic or eutopic endometrial tissue (Colette et al. 2009, Delvoux et al. 2009, 2014), others record expression in normal endometrium (Tseng 1984, Neulcn et al. 1987, Huang et al. 1989, Castro et al. 2010) and in endometrium from women with and without endometriosis (Aghajanova et al. 2009). Variations in the location of P450arom have also been recorded with detection in epithelial cells (Kitawaki et al. 1997, Bukulmez et al. 2008a, Castro et al. 2010), but mostly in stromal cells (Noble et al. 1996a, Zeitoun et al. 1999, Suganuma et al. 2014) (Supplementary Tables 3 and 4). Some of the variations in the reported patterns of expression may relate to use of different antibodies, recovery of eutopic endometrium at different stages of the cycle, the type of lesion or the status of the inflammatory microenvironment as discussed below.

A number of factors that are altered in endometriosis patients can induce the expression of P450arom. For instance, the observed increase in concentrations of androstenedione (Huhtinen et al. 2014) may induce P450arom expression in human endometrial stromal cells and the human endometrial surface epithelial (HES) cell line, as has been previously described (Bukulmez et al. $2008 b$ ). Inflammatory cells or inflammatory mediators may also have an impact. For example, P450arom protein and mRNA were enhanced by macrophage activity in endometrial stromal and endometrial cells, and macrophage inhibition significantly reduced P450arom expression (Veillat et al. 2012). In different experiments, treatments of stromal cells derived from ovarian endometrioma, with PGE-2 or IL-(1, 2, 4, 6, 11, 15) stimulated expression of P450arom in a time- and dosedependent manner (Noble et al. 1997, Urata et al. 2013, Zeng et al. 2015). Interestingly, in these experiments, eutopic endometrial cells showed low levels of P450arom mRNA expression and not upregulated by PGE-2 or ILs, suggesting there may be different responses in eutopic vs ectopic tissues.

Accordingly, in face of these conflicting results, controversy still exists with regard to the association between P450arom expression and clinical symptoms of endometriosis. Higher CYP17A1 GG genotype was linked to infertility although there were no differences between patients with endometriosis and patients without endometriosis (Szczepańska et al. 2013). In a study on 62 women with endometriosis, positive immunohistochemical expression for aromatase was detected in the endometriotic tissues from 38 patients (61.3\%): these patients were more likely to have ovarian disease and moderate-to-severe chronic pelvic pain (Acién et al. 2007).

\section{Pathways utilizing sulphated steroids}

Although the synthesis of E1 and E2 from the sulphated oestrogens (E1S and E2S, respectively) is usually considered less important than the aromatase pathway in the ovary, for peripheral tissues including the endometrium it seems to be an important alternative pathway that leads to increased bioavailability of local active oestrogens (reviewed by Rižner 2016). Thus, due 
to the possible impact that sulphonation pathway could have in oestrogen-dependent diseases, research groups around the world investigated the possible involvement of sulphated steroids and their respective enzymes in endometriosis (Purohit et al. 2008, Delvoux et al. 2014). Table 3 summarizes articles that study the main enzymes that utilize sulphated steroids including two forms of sulphotransferases (SULTs) not discussed below.

\section{Steroid sulphatase}

STS is the enzyme responsible for the hydrolysis of dehydroepiandrosterone sulphate, E1S and E2S into their unconjugated forms, DHEA, E1 and E2, respectively (Reed et al. 2005). Although the mRNA expression and activity of STS is increased in malignant endometrial tissues compared with nonmalignant tissues according to the majority of studies (Hevir et al. 2011, 2013), data on STS mRNA and protein expression have only recently emerged from studies on endometriosis. The expression of STS in endometriosis has been reviewed by Rižner 2009, where comparisons of STS expression in eutopic and ectopic tissue from the same patients as well as comparison of expression in ectopic tissue vs eutopic tissue of control patients were evidenced. Overall, most studies agree that there is a differential STS mRNA expression between eutopic and ectopic endometrium, in spite of conflicting results in regards of STS expression among endometriotic lesions. Data from our group show higher STS mRNA expression in deep-infiltrating and superficial lesions when compared to eutopic and normal endometrium, with neither differences between ectopic lesions, nor between eutopic and normal endometrium (Piccinato et al. 2016a). Some authors have reported higher STS mRNA expression in ovarian lesions when compared to endometrium from patients with myoma (Smuc et al. 2007, Šmuc et al. 2009), while others have not been able to detect differences between lesions, compared to the eutopic endometrium (Colette et al. 2013, Huhtinen et al. 2014). Similarly, in deep-infiltrating lesions, both an unaltered expression pattern (Dassen et al. 2007) and greater expression of STS mRNA expression relative to that in ovarian lesions have been described (Colette et al. 2013).

Only a few researchers have attempted to quantify STS protein expression. Collette et al. reported no differences in protein levels between tissues from endometriosis patients and controls (Colette et al. 2013). In contrast to that, Dassen et al. reported increased expression levels of

Table 3 mRNA expression of enzymes from pathways utilizing sulphated steroids.

\begin{tabular}{|c|c|c|c|c|}
\hline Enzyme & Patient number & Sample number & Differential expression & Reference \\
\hline \multirow[t]{4}{*}{ STS } & $E=60 ; C=16$ & $\mathrm{EL}=23 ; \mathrm{OE}=18 ; \mathrm{EE}=18 ; \mathrm{CE}=16$ & $\begin{array}{l}\mathrm{OE}=\mathrm{CE} \\
\mathrm{EE}=\mathrm{CE} \\
\mathrm{EL}=\mathrm{CE}\end{array}$ & Huhtinen et al. (2014) \\
\hline & $E=62 ; C=16$ & $\mathrm{EL}=34 ; \mathrm{EE}=24 ; \mathrm{CE}=25$ & $\uparrow \mathrm{EL} / \mathrm{EE} ; \mathrm{CE}$ & Piccinato et al. (2016a) \\
\hline & $E=16 ; C=9$ & $\mathrm{OCE}=16 ; \mathrm{COC}=9$ & $\uparrow \mathrm{OE} / \mathrm{COC}$ & Smuc et al. (2007) \\
\hline & $E=24 ; C=10$ & $\mathrm{OE}=24 ; \mathrm{CE}=10$ & $\uparrow \mathrm{OE} / \mathrm{CE}$ & Šmuc et al. (2009) \\
\hline \multirow[t]{5}{*}{ HSD17B1 } & $E=29 ; C=13$ & $\mathrm{EE}=7 ; \mathrm{CE}=6$ & $\mathrm{EE}=\mathrm{CE}$ & Aghajanova et al. (2009) \\
\hline & $E=29$ & $\mathrm{EL}=23 ; \mathrm{OE}=6 ; \mathrm{EE}=29$ & $\uparrow \mathrm{EL} ; \mathrm{OE} / \mathrm{EE}$ & Delvoux et al. (2014) \\
\hline & $E=60 ; C=16$ & $E L=23 ; O E=18 ; E E=18 ; C E=15$ & $\uparrow \mathrm{OE} / \mathrm{CE}$ & Huhtinen et al. $(2012 b)^{* * *}$ \\
\hline & $E=16 ; C=9$ & $\mathrm{OCE}=16 ; \mathrm{COC}=9$ & $\uparrow \mathrm{OE} / \mathrm{COC}$ & Smuc et al. (2007) \\
\hline & $E=24 ; C=10$ & $\mathrm{OE}=24 ; \mathrm{CE}=10$ & $\uparrow \mathrm{OE} / \mathrm{CE}$ & Šmuc et al. (2009) \\
\hline \multirow[t]{3}{*}{ SULT1A1 } & $E=79 ; C=41$ & $E L=30 ; O E=15 ; E E=33 ; C E=15$ & $\mathrm{EL}=\mathrm{OE}=\mathrm{EE}=\mathrm{CE}$ & Colette et al. (2013) \\
\hline & $E=31 ; C=29$ & $\mathrm{OE}=31 ; \mathrm{CE}=29$ & $\mathrm{OE}=\mathrm{CE}$ & Hevir et al. (2013) \\
\hline & $E=24 ; C=10$ & $\mathrm{OE}=24 ; \mathrm{CE}=10$ & $\mathrm{OE}=\mathrm{CE}$ & Šmuc et al. (2009) \\
\hline \multirow[t]{7}{*}{ SULT1E1 } & $E=79 ; C=41$ & $\mathrm{EL}=30 ; \mathrm{OE}=15 ; \mathrm{EE}=33 ; \mathrm{CE}=15$ & $\mathrm{EL}=\mathrm{OE}=\mathrm{EE}=\mathrm{CE}$ & Colette et al. (2013) \\
\hline & $E=14 ; C=48$ & $\mathrm{EL}=14 ; \mathrm{EE}=14 ; \mathrm{CE}=48$ & $\uparrow \mathrm{EL} / \mathrm{EE}$ & Dassen et al. (2007) \\
\hline & $E=31 ; C=29$ & $\mathrm{OE}=31 ; \mathrm{CE}=29$ & $\mathrm{OE}=\mathrm{CE}$ & Hevir et al. (2013) \\
\hline & $E=62 ; C=16$ & $\mathrm{EL}=34 ; \mathrm{EE}=24 ; \mathrm{CE}=25$ & $* \mathrm{EL}=\mathrm{EE}=\mathrm{CE}$ & Piccinato et al. (2016a) \\
\hline & $E=24 ; C=10$ & $\mathrm{OE}=24 ; \mathrm{CE}=10$ & $\mathrm{OE}=\mathrm{CE}$ & Šmuc et al. (2009) \\
\hline & $E=79 ; C=41$ & $\mathrm{EL}=30 ; \mathrm{OE}=15 ; \mathrm{EE}=33 ; \mathrm{CE}=15$ & $\mathrm{EL}=\mathrm{OE}=\mathrm{EE}=\mathrm{CE}$ & Colette et al. (2013) \\
\hline & $E=31 ; C=29$ & $\mathrm{OE}=31 ; \mathrm{CE}=29$ & $\uparrow \mathrm{OE} / \mathrm{CE}$ & Hevir et al. (2013) \\
\hline SULT2B1 & $E=24 ; C=10$ & $O E=24 ; C E=10$ & $\mathrm{OE}=\mathrm{CE}$ & Šmuc et al. (2009) \\
\hline
\end{tabular}

*Tendency of reduced expression; *** when comparing patients in the proliferative and secretory phase. It was considered significant all mRNA expression with $P<0.005$.

C, control patients - control patients are considered all women without endometriosis; $C E$, control endometrium; COC, control ovarian cyst; $E$, endometriosis patients; EE, eutopic endometrium from endometriosis; EL, endometriosis lesion-extraovarian; OCE, ovarian endometriotic cyst endometriosis; OE, ovarian endometriomas. 
STS in epithelial cells, but not in stromal cells, of normal endometrium when compared to eutopic endometrium from women with endometriosis, suggesting cell-specific enrichment of the enzyme (Dassen et al. 2007). These studies used immunohistochemical analysis, and no other studies have reported protein expression data, which may reflect problems with antibody quality. Despite the controversy in protein expression data, STS activity seems to be correlated with severity of the disease suggesting that the sulphate pathway might be involved with the underlying mechanisms that contribute to the severity of endometriosis (Purohit et al. 2008). A clear STS activity has been described in endometriosis lesions, with a high positive correlation between protein activity and severity of the disease (Dassen et al. 2007). Similarly, STS activity in ectopic tissues from minimal-to-mild endometriosis was significantly lower than similar samples collected from patients affected with a moderate-to-severe form of the disease (Purohit et al. 2008). In the same study, however, an intriguing overall lower activity in ectopic endometrium was detected when compared to eutopic endometrium (Purohit et al. 2008) and a lack of differential activity between eutopic and ectopic tissues was also reported in another study (Delvoux et al. 2009). Using an in vitro approach, endometrial and endometriotic stromal cells were incubated with E2S as a STS substrate for $2 \mathrm{~h}$. The result shows E2 concentrations higher in stromal cells from deep-infiltrating endometriotic lesions as compared to cells from eutopic endometrium from the same patient (Piccinato et al. 2016a). This finding suggests a greater efficiency of endometriotic stromal cells in metabolizing oestrogen sulphates, which might explain the ability of lesions to maintain an oestrogenic milieu. The regulation of STS activity and expression seems to be tissue specific (Dalla Valle et al. 2006, Zaichuk et al. 2007). In the endometrium, STS has been shown to be regulated by progesterone, according to menstrual cycle phases (Furusawa et al. 2002) with endometrium from the luteal phase of the cycle showing higher mRNA STS expression than that from the follicular phase in normal endometrium: the same observation made in endometriosis patients, for both eutopic and ectopic endometrium (Piccinato et al. 2016a). In the same study, STS expression was modulated by E2 and progesterone (representative steroid hormones from the luteal phase) in stromal endometriotic cells. Conversely, Dassen et al. found that STS mRNA expression was not affected by E2 or progesterone in explant endometrial culture (Dassen et al. 2007).

\section{HSD17B subtypes}

The 17- $\beta$-hydroxysteroid-dehydrogenase (HSD17B) enzymes play important roles in oestrogen biosynthesis in the sulphatase pathway. It is responsible for catalysing the oxidation and reduction of steroids, which means they activate and inactivate oestrogens, enabling them to bind with oestrogen receptors (Marchais-Oberwinkler et al. 2011). There are 15 HSD17B enzymes described today and with the exception of HSD17B5, an aldo-keto reductase enzyme, they all belong to short-chain dehydrogenase/ reductase family and are multimeric enzymes (He et al. 2016). For instance, 17BHSD2 is an oestrogen inactivator (E2 to E1) and expression of 17BHSD2 may be decreased in endometriosis (Bulun et al. 2010). Among all HSD17B family members, HSD17B1 is considered the most important enzyme for E2 production (Zhang et al. 2015). Of interest, a higher HSD17B1 expression has been linked to endometriosis and the severity of the disease (Supplementary Table 5) (Tsuchiya et al. 2005b, Smuc et al. 2007, Huhtinen et al. 2012b).

Gene transcripts for HSD17B1 have been found upregulated in endometriosis tissues (eutopic and/or ectopic endometrium) when compared with eutopic tissue from healthy women (Dassen et al. 2007, Smuc et al. 2007, Šmuc et al. 2009, Huhtinen et al. 2012a, Colette et al. 2013, Delvoux et al. 2014), although some reports show no detectable mRNA expression for HSD17B1 in normal endometrium (Casey et al. 1994). Results for protein expression appear less consistent, for instance, Dassen et al. found higher mRNA expression of HSD17B1, but less protein expression in endometriotic tissue compared to normal endometrium (Dassen et al. 2007). Others, studying HDS17B1 protein expression, demonstrated higher HDS17B1 activity in ectopic endometrium compared to eutopic endometrium from the same patient (Delvoux et al. 2009). Another group stated that there is no protein expression in normal endometrium (Utsunomiya 2001). Disparities in findings based on different types of endometriosis (ovarian, peritoneal and deep-infiltrating) and menstrual phase have also been reported. In one study when endometriotic sites were compared, no differences were seen in HSD17B1 transcript expression between ovarian, peritoneal and deep-infiltrating endometriosis (Colette et al. 2013). In another study, a significant increase in HSD17B1 mRNA expression in ovarian endometriosis compared to normal endometrium was reported (Huhtinen et al. 2012b). The menstrual phase did not appear to influence HSD17B1 mRNA expression in eutopic tissue from endometriosis 
patients or in non-endometriosis patients (Colette et al. 2013) and protein expression levels were also similar among different menstrual phases in both groups of women with and without endometriosis in other papers (Dassen et al. 2007, Colette et al. 2013).

\section{Sulphotransferases}

Oestrogen homeostasis is closely controlled by the balance between desulphonation and sulphation; therefore, the expression and activity of SULTs in a tissue can be considered as a mechanism that generates a reservoir of sulphated steroids that can be readily activated by STS. Overall, sulphation pathways include sulphate uptake, followed by conversion to an active sulphate in the form of 3-phospho-adenosine-5-phosphosulphate, and transfer to steroid hydroxyl groups by SULTs (reviewed by Mueller et al. 2015). The superfamily of steroid SULTs include members that have a direct role in oestrogen local metabolism, by catalysing the sulphonation of E1 and E2 with high affinity (E1 SULT SULT1E1, also called EST) or with low affinity (SULT1A1) (Adjei \& Weinshilboum 2002); but also members indirectly modulating local oestrogen concentrations by sulphonating precursors of oestrogen formation, as for instance SULT2B1 that acts preferentially on $3 \beta$-hydroxysteroids (Geese \& Raftogianis 2001).

E1 SULT is expressed in the endometrium and although it is not a steroid-synthesizing enzyme, it has been included in this review due to its impact on intra-tissue oestrogen concentrations (Rubin et al. 1999). SULT1E1 has a high affinity for physiological concentrations of E2 and E1 (Honma et al. 2002) and is the major SULT isoform responsible for oestrogen sulphation (Zhang et al. 1998). SULT1E1 is, therefore, an important downregulator of oestrogen activity and can protect cells/tissues from adverse effects of excess oestrogens.

Our own data on SULT1E1 shows tendency of increased expression of the enzyme in ovarian and peritoneal endometriotic lesions, as compared to eutopic endometrium of endometriosis patients (Piccinato et al. 2016a). Similar results were obtained by Dassen et al. who reported increased expression of SULT1E1 mRNA in endometriotic lesions (without lesion type classification), as compared to that in control endometrium (Dassen et al. 2007). However, the same differences were not detected in the samples from 15 patients examined by Colette et al. (2013). We and Dassen et al. also reported an overexpression of SULT1E1 during the luteal phase of the menstrual cycle samples (lesions and endometrium) from women with endometriosis, whereas cycle-dependent expression was not detected in endometrium of nonaffected women (Dassen et al. 2007, Piccinato et al. 2016a). Other groups have not detected evidence of menstrual cycle phase-dependent regulation in SULT1E1 expression (Colette et al. 2013, Hevir et al. 2013) or have not controlled for this variable in their analysis (Šmuc et al. 2009). The only data about SULT1E1 protein expression comes from an immunohistochemical study that shows no difference in SULT1E1 expression between eutopic and ectopic endometrium (Hudelist et al. 2007). However, no clear description of type of lesion was provided, suggesting that different kinds of lesions were included in the same group. Further studies with larger numbers of samples are needed to resolve the differences between these reports.

In oestrogen-sensitive tissues, such as the endometrium, the activity of SULT1E1 is generally lower than that of STS (Naitoh et al. 1989) promoting an increased bioavailability of active oestrogens, which may be further enhanced under pathological conditions. Although controversy still exists with regard to expression in tissue samples from women with endometriosis, reports of increased expression of SULT1E1 and co-expression of STS and SULT1E1 (Piccinato et al. 2016a) in endometriosis lesions as compared to control endometrium suggest that these enzymes might contribute to local generation of a reservoir of sulphated steroids that, upon deconjugation by STS, can support growth of lesions or progression of disease.

\section{Other levels of control of oestrogen accumulation in endometriotic lesions}

Metabolizing enzymes While emphasis is often placed on the role of the enhancement of E2 biosynthesis pathways, there is increasing evidence that enzymes involved in the metabolism/inactivation of oestrogens have a role in the regulation of local oestrogen homeostasis in lesions. The mechanisms by which altered oestrogen-metabolizing enzymes could potentially be involved with the pathogenesis of endometriosis ranges from reduction of local oestrogen (Piccinato et al 2016a STS) to increase in the reactive oxidative species in endometriotic lesions (Hevir et al. 2013). Besides SULT1E1, other phase II (conjugative) metabolizing enzymes such as catechol-O-methyltransferase (COMT) and uridine diphospho-glucuronosyltransferase (UGT) and even phase I oxidative enzymes (as for instance, CYP1A1 and CYP3A4) can reduce or block oestrogen availability in endometriotic lesions, representing an important regulatory mechanism of oestrogen action. 
Data from our group (Piccinato et al. 2016a,b,c) and reports from others (Hevir et al. 2013) show that enzymes classically involved in extra-hepatic oestrogen metabolism are upregulated in endometriotic lesions. It should be noted that the expression of these metabolizing enzymes may be influenced by the location of the lesion. For example, it has been reported that expression of CYP1A1 and CYP1B1 enzymes is higher in superficial lesions in comparison to eutopic endometrium or deep-infiltrating lesions (Huhtinen et al. 2014, Piccinato et al. 2016a). In addition, mRNA and protein encoded by UGT1A1 were low or absent in eutopic endometrium, whereas it was possible to detect the enzyme in almost all types of lesions, most prominently in deep-infiltrating lesions, but also in superficial peritoneal and ovarian lesions. It is important to highlight that the metabolism of oestrogens not only alters the intensity of their action but may also alter the profile of their physiological effects in target tissues (Tsuchiya et al. 2005a). Although speculative, it appears that the progression of endometriosis can be influenced by the expression and activity of enzymes involved in the metabolism of oestrogens.

Cellular transport of sulphated oestrogens Sulphated steroids, such as E1S or E2S are hydrophilic, organic anions that need specific active transmembrane transport for cellular influx and efflux (reviewed by Mueller et al. 2015). This active cellular transport is regulated by numerous membrane-bound proteins that belong to two superfamilies: solute carrier (SLC) transporters and ATP-binding cassette (ABC) transporters (Roth et al. 2012). Very little is known about how E1S is transported into cells in the endometrium or lesions (Plaza-Parrochia et al. 2015). In different tissues, it seems that a variety of organic anion transporting polypeptides and SLC21 (all belonging to the SLC family) can carry E1S from the extracellular space to the intracellular space (reviewed by Secky et al. 2013). The efflux of E1S is, in turn, actively promoted by ABC transporters, called MRP1 and BCRP. In summary, the combined activity of transmembrane protein transporters, metabolizing enzymes and synthesizing enzymes can regulate the amount of sulphated oestrogen and, thus, the amount of bioactive oestrogen within tissues.

\section{Summary and future directions}

Endometriosis is an incurable disorder characterized by inflammation and hormone dependence. Oestrogens acting via oestrogen receptors regulate processes including proliferation, angiogenesis, inflammation and differentiation, which are important in regulation of normal endometrium, endometrial pathologies (hyperplasia and adenocarcinoma) and have been implicated in the establishment of endometriosis lesions. In vitro studies using isolated cells have suggested that pro-inflammatory mediators such as PGE2 can stimulate expression of the steroidogenic enzymes detected in lesions providing a mechanism linking these two hallmarks of the disease.

Studies on endometrium and endometriosis lesions have provided compelling evidence that (intracrine) oestrogen biosynthesis associated with dysregulation of enzyme expression occurs in endometriosis. Indeed, oestrogen accumulation is defined by the balance of synthesis and inactivation/metabolism, and it seems that metabolism might play a previously underappreciated role as several key metabolizing enzymes are upregulated in endometriotic tissue. The primary sites of synthesis of the bioactive oestrogens (E1, E2) that circulate in the bloodstream are the ovarian follicles but expression of steroid-metabolizing enzymes in extraovarian sites can have a significant impact on the local concentrations of steroids in the tissue microenvironment. Expression of enzymes representing all key steps in the de novo steroidogenic pathway, including aromatase, has been detected. An alternative source of E1 and E2 are conjugated steroids found in the blood bathing the lesions and the discovery that the STS enzyme which uses E1S and E2S as substrate, when appropriate uptake transporters are expressed in lesions has opened up an alternative mechanism to explain the higher concentrations of E2 detected in lesions using LC/MS-MS.

Treatments focused on modulation of the enzymes that regulate local (intracrine) actions of oestrogens in lesions are being actively explored as these offers the promise of capitalizing on the proven success of regimes that suppress ovarian steroid production in reducing pain symptoms but without acting as contraceptives. AIs have been effective in the treatment of breast cancer and some reports suggest AI can also relieve endometriosisassociated symptoms (Attar \& Bulun 2006). Evidence of limitations on the use of $\mathrm{AI}$ alone or in combination for endometriosis-related chronic pelvic pain and infertility treatment have been reviewed (Pavone \& Bulun 2012, Dunselman et al. 2014). Notably, recent data suggest new local (vaginal) routes of delivery should receive more attention and testing (Buggio et al. 2017). Inhibitors of AKR1C3 are an attractive option because the enzyme is active in both the steroid and prostaglandin pathways: 
drugs have been developed for clinical indications including castration resistant prostate cancer and breast cancer (reviewed in Penning 2017). Bayer has developed an AKR1C3 inhibitor (BAY 1128688) for the treatment of endometriosis and this is reported in phase I completed clinical trial (ClinicalTrials.gov Identifier: NCT02434640) that led to a recently initiated phase II clinical trial. A number of STS inhibitors have been developed with the primary clinical indication being hormone-dependent cancers (Purohit \& Foster 2012) and shown to be well tolerated in phase I clinical trials for breast cancer (Stanway et al. 2006). The STS inhibitor EMATE was shown to have an impact on lesions in mouse models (Colette et al. 2011), and there is a proof-of-principle report regarding the use of this STS inhibitor in combination with a progestin to treat women with endometriosis (Pohl et al. 2014) offering promising new therapeutic approach worthy of further investigation. To date, there have not been any studies using drugs targeting SULT1E1 or membrane transporters, but these offer additional novel targets.

In summary, there is increasing interest in the potential for targeting enzymes involved in generation of a pro-oestrogenic microenvironment in lesions as a novel fertility-sparing therapy for women with endometriosis. As new drugs become available, we can expect to see an acceleration and expansion of both basic and clinical studies and trials.

\section{Supplementary data}

This is linked to the online version of the paper at https://doi.org/10.1530/ JME-17-0297.

\section{Declaration of interest}

The authors declare that there is no conflict of interest that could be perceived as prejudicing the impartiality of this review.

\section{Funding}

This work was partially supported by the São Paulo Research Foundation (FAPESP: 2010/02412-6). D A G is employed on a grant from the UK Medical Research Council that also supports research activity in the Saunders laboratory (GMR/N024524/1). C A P is a visiting scientist supported by an institutional grant from Sociedade Beneficiente Israelita Brasileira Albert Einstein.

\section{References}

Acién P, Velasco I, Gutiérrez M \& Martínez-Beltrán M 2007 Aromatase expression in endometriotic tissues and its relationship to clinical and analytical findings. Fertility and Sterility 88 32-38. (https://doi. org/10.1016/j.fertnstert.2006.11.188
Adjei AA \& Weinshilboum RM 2002 Catecholestrogen sulfation: possible role in carcinogenesis. Biochemical and Biophysical Research Communications 292 402-408. (https://doi.org/10.1006/ bbrc.2002.6658)

Agarwal A, Gupta S \& Sharma RK 2005 Role of oxidative stress in female reproduction. Reproductive Biology and Endocrinology 3 28. (https:// doi.org/10.1186/1477-7827-3-28)

Aghajanova L, Hamilton A, Kwintkiewicz J, Vo KC \& Giudice LC 2009 Steroidogenic enzyme and key decidualization marker dysregulation in endometrial stromal cells from women with versus without endometriosis. Biology of Reproduction 80 105-114. (https://doi. org/10.1095/biolreprod.108.070300)

American Society for Reproductive Medicine 1997 Revised American Society for Reproductive Medicine classification of endometriosis: 1996. Fertility and Sterility 67 817-821. (https://doi.org/10.15270/433-276)

Attar E \& Bulun SE 2006 Aromatase inhibitors: the next generation of therapeutics for endometriosis? Fertility and Sterility 85 1307-1318. (https://doi.org/10.1016/j.fertnstert.2005.09.064)

Attar E, Tokunaga H, Imir G, Yilmaz MB, Redwine D, Putman M, Gurates B, Attar R, Yaegashi N, Hales DB, et al. 2009 Prostaglandin E2 via steroidogenic factor-1 coordinately regulates transcription of steroidogenic genes necessary for estrogen synthesis in endometriosis. Journal of Clinical Endocrinology and Metabolism 94 623-663. (https://doi.org/10.1210/jc.2008-1180)

Bellelis P, Podgaec S \& Abrão MS 2014 Fatores ambientais e endometriose: um ponto de vista. Revista Brasileira de Ginecologia E Obstetrícia 36 433-435. (https://doi.org/10.1590/SO100720320140005128)

Blakemore J \& Naftolin F 2016 Aromatase: contributions to physiology and disease in women and men. Physiology 31 258-269. (https://doi. org/10.1152/physiol.00054.2015)

Borghese B, Mondon F, Noël J-C, Fayt I, Mignot T-M, Vaiman D \& Chapron C 2008 Gene expression profile for ectopic versus eutopic endometrium provides new insights into endometriosis oncogenic potential. Molecular Endocrinology 22 2557-2562. (https://doi. org/10.1210/me.2008-0322)

Buggio L, Lazzari C, Monti E, Barbara G, Berlanda N \& Vercellini P 2017 'Per vaginam' topical use of hormonal drugs in women with symptomatic deep endometriosis: a narrative literature review. Archives of Gynecology and Obstetrics 296 435-444. (https://doi. org/10.1007/s00404-017-4448-z)

Bukulmez O, Hardy DB, Carr BR, Word RA \& Mendelson CR $2008 a$ Inflammatory status influences aromatase and steroid receptor expression in endometriosis. Endocrinology 149 1190-1204. (https:// doi.org/10.1210/en.2007-0665)

Bukulmez O, Hardy DB, Carr BR, Auchus RJ, Toloubeydokhti T, Word RA \& Mendelson CR 2008 $b$ Androstenedione up-regulation of endometrial aromatase expression via local conversion to estrogen: potential relevance to the pathogenesis of endometriosis. Journal of Clinical Endocrinology and Metabolism 93 3471-3477. (https://doi. org/10.1210/jc.2008-0248)

Bulletti C, Coccia ME, Battistoni S \& Borini A 2010 Endometriosis and infertility. Journal of Assisted Reproduction and Genetics 27 441-447. (https://doi.org/10.1007/978-1-4471-4953-8_3)

Bulun SE, Fang Z, Imir G, Gurates B, Tamura M, Yilmaz B, Langoi D, Amin S, Yang S \& Deb S 2004 Aromatase and endometriosis. Seminars in Reproductive Medicine 22 45-50. (https://doi. org/10.1055/s-2004-823026)

Bulun SE, Cheng Y, Pavone ME, Yin P, Imir G, Utsunomiya H, Thung S, Xue Q, Marsh EE, Tokunaga H, et al. 2010 17Beta-hydroxysteroid dehydrogenase-2 deficiency and progesterone resistance in endometriosis. Seminars in Reproductive Medicine 28 44-50. (https:// doi.org/10.1055/s-0029-1242992.17)

Bulun SE, Monsavais D, Pavone ME, Dyson M, Xue Q, Attar E, Tokunaga H \& Su EJ 2012 Role of estrogen receptor- $\beta$ in 
endometriosis serdar. Seminars in Reproductive Medicine 30 39-45. (https://doi.org/10.1055/s-0031-1299596.Role)

Burney RO, Talbi S, Hamilton AE, Kim CV, Nyegaard M, Nezhat CR, Lessey BA \& Giudice LC 2007 Gene expression analysis of endometrium reveals progesterone resistance and candidate susceptibility genes in women with endometriosis. Endocrinology 148 3814-3826. (https://doi.org/10.1210/en.2006-1692)

Burris TP, Solt LA, Wang Y, Crumbley C, Banerjee S, Griffett K, Lundasen T, Hughes T \& Kojetin DJ 2013 Nuclear receptors and their selective pharmacologic modulators. Pharmacological Reviews 65 710-778. (https://doi.org/10.1124/pr.112.006833)

Casey ML, MacDonald PC \& Andersson S 199417 beta-Hydroxysteroid dehydrogenase type 2: chromosomal assignment and progestin regulation of gene expression in human endometrium. Journal of Clinical Investigation 94 2135-2141. (https://doi.org/10.1172/ JCI117569)

Castro J, Torres M, Sovino H, Fuentes A, Boric MA \& Johnson MC 2010 P450Arom induction in isolated control endometrial cells by peritoneal fluid from women with endometriosis. Fertility and Sterility 94 2521-2527. (https://doi.org/10.1016/j.fertnstert.2010.03.036)

Catalano RD, Wilson MR, Boddy SC \& Jabbour HN 2011 Comprehensive expression analysis of prostanoid enzymes and receptors in the human endometrium across the menstrual cycle. Molecular Human Reproduction 17 182-192. (https://doi.org/10.1093/molehr/gaq094)

Chapron C, Chopin N, Borghese B, Foulot H, Dousset B, VacherLavenu MC, Vieira M, Hasan W \& Bricou A 2006 Deeply infiltrating endometriosis: pathogenetic implications of the anatomical distribution. Human Reproduction 21 1839-1845. (https://doi. org/10.1093/humrep/del079)

Colette $\mathrm{S}$, Lousse JC, Defrère $\mathrm{S}$, Curaba $\mathrm{M}$, Heilier JF, Van Langendonckt A, Mestdagt M, Foidart JM, Loumaye E \& Donnez J 2009 Absence of aromatase protein and mRNA expression in endometriosis. Human Reproduction 24 2133-2141. (https://doi. org/10.1093/humrep/dep199)

Colette S, Defrère S, Lousse JC, Van Langendonckt A, Gotteland JP, Loumaye E \& Donnez J 2011 Inhibition of steroid sulfatase decreases endometriosis in an in vivo murine model. Human Reproduction 26 1362-1370. (https://doi.org/10.1093/humrep/der079)

Colette S, Defrère S, Van Kerk O, Van Langendonckt A, Dolmans MM \& Donnez J 2013 Differential expression of steroidogenic enzymes according to endometriosis type. Fertility and Sterility 100 1642-1649. (https://doi.org/10.1016/j.fertnstert.2013.08.003)

Critchley HOD, Brenner RM, Teresa A. H, Karin W, Nihar R. N, Slayden OD, Millar MR \& Saunders PTK 2001 Estrogen receptor beta, but not estrogen receptor alpha, is present in the vascular endothelium of the human and nonhuman primate endometrium. Journal of Clinical Endocrinology and Metabolism 86 1370-1378. (https://doi.org/10.1210/jc.86.3.1370)

Culley L, Law C, Hudson N, Denny E, Mitchell H, Baumgarten M \& Raine-Fenning N 2013 The social and psychological impact of endometriosis on women's lives: a critical narrative review. Human Reproduction Update 19 625-639. (https://doi.org/10.1093/humupd/ dmt027)

Dalla Valle L, Toffolo V, Nardi A, Fiore C, Bernante P, Di Liddo R, Parnigotto PP \& Colombo L 2006 Tissue-specific transcriptional initiation and activity of steroid sulfatase complementing dehydroepiandrosterone sulfate uptake and intracrine steroid activations in human adipose tissue. Journal of Endocrinology 190 129-139. (https://doi.org/10.1677/joe.1.06811)

Dassen H, Punyadeera C, Kamps R, Delvoux B, Van Langendonckt A, Donnez J, Husen B, Thole H, Dunselman G \& Groothuis P 2007 Estrogen metabolizing enzymes in endometrium and endometriosis. Human Reproduction 22 3148-3158. (https://doi.org/10.1093/humrep/ dem310)

De Graaff AA, D'hooghe TM, Dunselman GAJ, Dirksen CD, Hummelshoj L, Simoens S, Bokor A, Brandes I, Brodszky V, Canis M, et al. 2013 The significant effect of endometriosis on physical, mental and social wellbeing: Results from an international crosssectional survey. Human Reproduction 28 2677-2685. (https://doi. org/10.1093/humrep/det284)

De Graaff AA, Dirksen CD, Simoens S, De Bie B, Hummelshoj L, D'Hooghe TM \& Dunselman GAJ 2015 Quality of life outcomes in women with endometriosis are highly influenced by recruitment strategies. Human Reproduction 30 1331-1341. (https://doi. org/10.1093/humrep/dev084)

De Leo B, Esnal-Zufiaurre A, Collins F, Critchley HOD \& Saunders PTK 2017 Immunoprofiling of human uterine mast cells identifies three phenotypes and expression of ER $\beta$ and glucocorticoid receptor. F1000Research 6 667. (https://doi.org/10.12688/ f1000research.11432.1)

Delvoux B, Groothuis P, D'Hooghe T, Kyama C, Dunselman G \& Romano A 2009 Increased production of 17B-estradiol in endometriosis lesions is the result of impaired metabolism. Journal of Clinical Endocrinology and Metabolism 94 876-883. (https://doi. org/10.1210/jc.2008-2218)

Delvoux B, D’Hooghe T, Kyama C, Koskimies P, Hermans RJJ, Dunselman GA \& Romano A 2014 Inhibition of type 1 $17 \beta$-hydroxysteroid dehydrogenase impairs the synthesis of $17 \beta$-estradiol in endometriosis lesions. Journal of Clinical Endocrinology and Metabolism 99 276-284. (https://doi.org/10.1210/ jc.2013-2851)

Devore NM \& Scott EE 2012 Cancer drugs abiraterone and Tok-001. Nature 482 116-119. (https://doi.org/10.1038/nature10743. CYTOCHROME)

Dunselman GAJ, Vermeulen N, Becker C, Calhaz-Jorge C, D'Hooghe T, De Bie B, Heikinheimo O, Horne AW, Kiesel L, Nap A, et al. 2014 ESHRE guideline: management of women with endometriosis. Human Reproduction 29 400-412. (https://doi.org/10.1093/humrep/ det457)

Endo S, Matsunaga T, Ohta C, Soda M, Kanamori A, Kitade Y, Ohno S, Tajima K, El-Kabbani O \& Hara A 2011 Roles of rat and human aldoketo reductases in metabolism of farnesol and geranylgeraniol. Chemico-Biological Interactions 191 261-268. (https://doi. org/10.1016/j.cbi.2010.12.017)

Eskenazi B \& Warner ML 1997 Epidemiology of endometriosis. Obstetrics and Gynecology Clinics of North America 24 235-. (https://doi. org/10.1136/jech.47.2.84)

Ferrero S, Remorgida V, Maganza C, Venturini PL, Salvatore S, Papaleo E, Candiani M \& Leone Roberti Maggiore U 2014 Aromatase and endometriosis: estrogens play a role. Annals of the New York Academy of Sciences. (https://doi.org/10.1111/nyas.12411)

Fouquet B, Santulli P, Noel JC \& Misrahi M 2016 Ovarian-like differentiation in eutopic and ectopic endometrioses with aberrant FSH receptor, INSL3 and GATA4/6 expression. BBA Clinical 6 143-152. (https://doi.org/10.1016/j.bbacli.2016.11.002)

Fuldeore M, Yang H, Du EX, Soliman AM, Wu EQ \& Winkel C 2015 Healthcare utilization and costs in women diagnosed with endometriosis before and after diagnosis: a longitudinal analysis of claims databases. Fertility and Sterility 103 163-171. (https://doi. org/10.1016/j.fertnstert.2014.10.011)

Furusawa Y, Matsuoka R, Yanaihara A, Toma Y, Taro Morimoto, Yuasa T, Tahara R, Saito H \& Okai T 2002 Regulation of estrogen activity in human endometrium: effect of IL-1beta on steroid sulfatase activity in human endometrial stromal cells. Showa University Journal of Medical Sciences 14 191-197. (https://doi.org/10.15369/ sujms1989.14.191)

Geese WJ \& Raftogianis RB 2001 Biochemical characterization and tissue distribution of human SULT2B1. Biochemical and Biophysical Research Communications 288 280-289. (https://doi.org/10.1006/ bbrc.2001.5746)

Ghosh S, Ashcraft K, Jahid MJ, April C, Ghajar CM, Ruan J, Wang H, Foster M, Hughes DC, Ramirez AG, et al. 2013 Regulation of adipose 
oestrogen output by mechanical stress. Nature Communications 4 1821. (https://doi.org/10.1038/ncomms2794)

Gibson DA, McInnes KJ, Critchley HOD \& Saunders PTK 2013 Endometrial intracrinology - generation of an estrogen-dominated microenvironment in the secretory phase of women. Journal of Clinical Endocrinology and Metabolism 98. (https://doi.org/10.1210/ jc.2013-2140)

Gibson DA, Greaves E, Critchley HOD \& Saunders PTK 2015 Estrogendependent regulation of human uterine natural killer cells promotes vascular remodelling via secretion of CCL2. Human Reproduction 30 1290-1301. (https://doi.org/10.1093/humrep/dev067)

Gibson DA, Simitsidellis I, Cousins FL, Critchley HOD \& Saunders PTK 2016 Intracrine androgens enhance decidualization and modulate expression of human endometrial receptivity genes. Scientific Reports 6 19970. (https://doi.org/10.1038/srep19970)

Giudice LC \& Kao LC 2004 Endometriosis. Lancet 364 1789-1799. (https://doi.org/10.1016/S0140-6736(04)17403-5)

Gopalakrishnan Radhika A, Chawla S, Nanda P, Yadav G \& Radhakrishnan G 2016 A multivariate analysis of correlation between severity and duration of symptoms, patient profile and stage of endometriosis. Open Journal of Obstetrics and Gynecology 6 615-622. (https://doi.org/10.4236/ojog.2016.610077)

Greaves E, Collins F, Critchley HOD \& Saunders PTK 2013 ERßdependent effects on uterine endothelial cells are cell specific and mediated via Sp1. Human Reproduction 28 2490-2501. (https://doi. org/10.1093/humrep/det235)

Greaves E, Collins F, Esnal-Zufiaurre A, Giakoumelou S, Horne AW \& Saunders PTK 2014 Estrogen receptor (ER) agonists differentially regulate neuroangiogenesis in peritoneal endometriosis via the repellent factor SLIT3. Endocrinology 155 4015-4026. (https://doi. org/10.1210/en.2014-1086)

Greaves E, Temp J, Esnal-Zufiurre A, Mechsner S, Horne AW \& Saunders PTK 2015 Estradiol is a critical mediator of macrophagenerve cross talk in peritoneal endometriosis. American Journal of Pathology 185 2286-2297. (https://doi.org/10.1016/j. ajpath.2015.04.012)

Greaves E, Critchley HOD, Horne AW \& Saunders PTK 2017 Relevant human tissue resources and laboratory models for use in endometriosis research. Acta Obstetricia et Gynecologica Scandinavica 96 644-658. (https://doi.org/10.1111/aogs.13119)

Guo SW 2009 Recurrence of endometriosis and its control. Human Reproduction Update 15 441-461. (https://doi.org/10.1093/humupd/ dmp007)

Guo SW, Hummelshoj L, Olive DL, Bulun SE, D'Hooghe TM \& Evers JLH 2009 A call for more transparency of registered clinical trials on endometriosis. Human Reproduction 24 1247-1254. (https://doi. org/10.1093/humrep/dep045)

Gupta D, Hull M, Fraser I, Miller L, Bossuyt P, Johnson N \& Nisenblat V 2016 Endometrial biomarkers for the non-invasive diagnosis of endometriosis (review). Cochrane Library 1-231. (https://doi. org/10.1002/14651858.CD012165)

Halpern G, Schor E \& Kopelman A 2015 Nutritional aspects related to endometriosis. Revista Da Associação Médica Brasileira (1992) 61 519-523. (https://doi.org/10.1590/1806-9282.61.06.519)

Harris HA 2007 Preclinical characterization of selective estrogen receptor $\beta$ agonists: new insights into their therapeutic potential. TissueSpecific Estrogen Action 149-162.

Harwood DT \& Handelsman DJ 2009 Development and validation of a sensitive liquid chromatography-tandem mass spectrometry assay to simultaneously measure androgens and estrogens in serum without derivatization. Clinica Chimica Acta 409 78-84. (https://doi. org/10.1016/j.cca.2009.09.003)

He W, Gauri M, Li T, Wang R \& Lin SX 2016 Current knowledge of the multifunctional 17B-hydroxysteroid dehydrogenase type 1 (HSD17B1). Gene 588 54-61. (https://doi.org/10.1016/j. gene.2016.04.031)
Henderson TA, Saunders PTK, Moffett-King A, Groome NP \& Critchley HOD 2003 Steroid receptor expression in uterine natural killer cells. Journal of Clinical Endocrinology and Metabolism $\mathbf{8 8}$ 440-449. (https://doi.org/10.1210/jc.2002-021174)

Hevir N, Vouk K, Šinkovec J, Ribič-Pucelj M \& Lanišnik Rižner T 2011 Aldo-keto reductases AKR1C1, AKR1C2 and AKR1C3 may enhance progesterone metabolism in ovarian endometriosis. ChemicoBiological Interactions 191 217-226. (https://doi.org/10.1016/j. cbi.2011.01.003)

Hevir N, Ribič-Pucelj M \& Lanišnik Rižner T 2013 Disturbed balance between phase I and II metabolizing enzymes in ovarian endometriosis: a source of excessive hydroxy-estrogens and ROS? Molecular and Cellular Endocrinology 367 74-84. (https://doi. org/10.1016/j.mce.2012.12.019)

Hewitt SC, Winuthayanon W, Lierz SL, Hamilton KJ, Donoghue LJ, Ramsey JT, Grimm SA, Arao Y \& Korach KS 2017 Role of ER $\alpha$ in mediating female uterine transcriptional responses to IGF1. Endocrinology 158 2427-2435. (https://doi.org/10.1210/en.2017-00349)

Hompes PGA \& Mijatovic V 2007 Endometriosis: the way forward. Gynecological Endocrinology 23 5-12. (https://doi. org/10.1080/09513590601010474)

Honma S, Shimodaira K, Shimizu Y, Tsuchiya N, Saito H, Yanaihara T \& Okai T 2002 The influence of inflammatory cytokines on estrogen production and cell proliferation in human breast cancer cells. Endocrine Journal 49 371-377. (https://doi.org/10.1507/ endocrj.49.371)

Hsu C-C, Lu C-W, Huang B-M, Wu M-H \& Tsai S-J 2008 Cyclic adenosine $3^{\prime}, 5^{\prime}$-monophosphate response element-binding protein and CCAAT/enhancer-binding protein mediate prostaglandin E2-induced steroidogenic acute regulatory protein expression in endometriotic stromal cells. American Journal of Pathology 173 433-441. (https://doi.org/10.2353/ajpath.2008.080199)

Huang JR, Bellino FL, Osawa Y \& Tseng L 1989 Immunologic identification of the aromatase enzyme system in human endometrium. Journal of Steroid Biochemistry 33 1043-1047. (https:// doi.org/10.1016/0022-4731(89)90407-X)

Hudelist G, Czerwenka K, Keckstein J, Haas C, Fink-Retter A, Gschwantler-Kaulich D, Kubista E \& Singer CF 2007 Expression of aromatase and estrogen sulfotransferase in eutopic and ectopic endometrium: evidence for unbalanced estradiol production in endometriosis. Reproductive Sciences 14 798-805. (https://doi. org/10.1177/1933719107309120)

Huhtinen K, Ståhle M, Perheentupa A \& Poutanen M 2012a Estrogen biosynthesis and signaling in endometriosis. Molecular and Cellular Endocrinology 358 146-154. (https://doi.org/10.1016/j. mce.2011.08.022)

Huhtinen K, Desai R, Stahle M, Salminen A, Handelsman DJ, Perheentupa A \& Poutanen M $2012 b$ Endometrial and endometriotic concentrations of estrone and estradiol are determined by local metabolism rather than circulating levels. Journal of Clinical Endocrinology and Metabolism 97 4228-4235. (https://doi. org/10.1210/jc.2012-1154)

Huhtinen K, Saloniemi-Heinonen T, Keski-Rahkonen P, Desai R, Laajala D, Stahle M, Hakkinen MR, Awosanya M, Suvitie P, Kujari H, et al. 2014 Intra-tissue steroid profiling indicates differential progesterone and testosterone metabolism in the endometrium and endometriosis lesions. Journal of Clinical Endocrinology and Metabolism 99 2188-2197. (https://doi.org/10.1210/jc.2014-1913)

Kennedy S 1999 The genetics of endometriosis. European Journal of Obstetrics and Gynecology and Reproductive Biology 82 129-133. (https://doi.org/10.1111/j.1749-6632.1999.tb07894.x)

Kim JH, Cho HT \& Kim YJ 2014 The role of estrogen in adipose tissue metabolism: insights into glucose homeostasis regulation. Endocrine Journal 61 1055-1067. (https://doi.org/10.1507/endocrj.EJ14-0262)

Kim LY, Kim MR, Kim JH \& Cho HH 2017 Aldo-keto reductase activity after diethylhexyl phthalate exposure in eutopic and ectopic 
endometrial cells. European Journal of Obstetrics and Gynecology and Reproductive Biology 215 215-219. (https://doi.org/10.1016/j. ejogrb.2017.05.018)

Kitawaki J, Noguchi T, Amatsu T, Maeda K, Tsukamoto K, Yamamoto T, Fushiki S, Osawa Y \& Honjo H 1997 Expression of aromatase cytochrome $\mathrm{P} 450$ protein and messenger ribonucleic acid in human endometriotic and adenomyotic tissues but not in normal endometrium. Biology of Reproduction 57 514-519. (https://doi. org/10.1095/biolreprod57.3.514)

Kitawaki J, Kusuki I, Koshiba H, Tsukamoto K \& Honjo H 1999 Detection of aromatase cytochrome P-450 in endometrial biopsy specimens as a diagnostic test for endometriosis. Fertility and Sterility 72 1100-1106. (https://doi.org/10.1016/S0015-0282(99)00424-0)

Králíčková M \& Vetvicka V 2015 Immunological aspects of endometriosis: a review. Annals of Translational Medicine 3153. (https://doi.org/10.3978/j.issn.2305-5839.2015.06.08)

Kyama CM, Debrock S, Mwenda JM \& D'Hooghe TM 2003 Potential involvement of the immune system in the development of endometriosis. Reproductive Biology and Endocrinology 1 123. (https:// doi.org/10.1186/1477-7827-1-123)

Labrie F, Luu-The V, Lin S-X, Simard J, Labrie C, El-Alfy M, Pelletier G \& Bélanger A 2000 Intracrinology: role of the family of 17 betahydroxysteroid dehydrogenases in human physiology and disease. Journal of Molecular Endocrinology 25 1-16. (https://doi.org/10.1677/ jme.0.0250001)

Lessey BA, Metzger DA, Haney AF \& McCarty KS Jr 1989 Immunohistochemical analysis of estrogen and progesterone receptors in endometriosis: comparison with normal endometrium during the menstrual cycle and the effect of medical therapy. Fertility and Sterility $\mathbf{5 1}$ 409-415. (https://doi.org/10.1016/S00150282(16)60545-9)

Liang Y \& Yao S 2016 Potential role of estrogen in maintaining the imbalanced sympathetic and sensory innervation in endometriosis. Molecular and Cellular Endocrinology 424 42-49. (https://doi. org/10.1016/j.mce.2016.01.012)

Lindsay SF, Luciano DE \& Luciano AA 2015 Emerging therapy for endometriosis. Expert Opinion on Emerging Drugs 8214 1-13. (https:// doi.org/10.1517/14728214.2015.1051966)

Marchais-Oberwinkler S, Henn C, Möller G, Klein T, Negri M, Oster A, Spadaro A, Werth R, Wetzel M, Xu K, et al. 2011 17B-Hydroxysteroid dehydrogenases (17B-HSDs) as therapeutic targets: protein structures, functions, and recent progress in inhibitor development. Journal of Steroid Biochemistry and Molecular Biology 125 66-82. (https://doi. org/10.1016/j.jsbmb.2010.12.013)

Montgomery GW, Nyholt DR, Zhao ZZ, Treloar SA, Painter JN, Missmer SA, Kennedy SH \& Zondervan KT 2008 The search for genes contributing to endometriosis risk. Human Reproduction Update $\mathbf{1 4}$ 447-457. (https://doi.org/10.1093/humupd/dmn016)

Morsch DM, Carneiro MM, Lecke SB, Araújo FC, Camargos AF, Reis FM \& Spritzer PM 2009 C-fos gene and protein expression in pelvic endometriosis: a local marker of estrogen action. Journal of Molecular Histology 40 53-58. (https://doi.org/10.1007/s10735-009-9212-7)

Mueller JW, Gilligan LC, Idkowiak J, Arlt W \& Foster PA 2015 The regulation of steroid action by sulfation and desulfation. Endocrine Reviews 36 526-563. (https://doi.org/10.1210/er.2015-1036)

Naitoh K, Honjo H, Yamamoto T, Urabe M, Ogino Y, Yasumura T \& Nambara T 1989 Estrone sulfate and sulfatase activity in human breast cancer and endometrial cancer. Journal of Steroid Biochemistry 33 1049-1054. (https://doi.org/10.1016/0022-4731(89)90408-1)

Nelson LR \& Bulun SE 2001 Estrogen production and action. Journal of the American Academy of Dermatology 45 116-124. (https://doi. org/10.1067/mjd.2001.117432)

Neulcn J, Hartmann C \& Breckwoldt M 1987 Aromatase activity in monolayer cell cultures of human endometrium. Gynecological Endocrinology 1 339-343. (https://doi. org/10.3109/09513598709082706
Nikoo S, Ebtekar M, Jeddi-Tehrani M, Shervin A, Bozorgmehr M, Vafaei S, Kazemnejad S \& Zarnani AH 2014 Menstrual blood-derived stromal stem cells from women with and without endometriosis reveal different phenotypic and functional characteristics. Molecular Human Reproduction 20 905-918. (https://doi.org/10.1093/molehr/ gau044)

Nilsson S, Mäkelä S, Treuter E, Tujague M, Thomsen J, Andersson G, Enmark E, Pettersson K, Warner M \& Gustafsson JA 2001 Mechanisms of estrogen action. Physiological Reviews 81 1535-1565. (https://doi.org/10.1152/physrev.2001.81.4.1535)

Nisenblat V, Bossuyt P, Shaikh R, Farquhar C, Jordan V, Scheffers C, Mol B \& Johnson N 2016 Blood biomarkers for the non-invasive diagnosis of endometriosis. Cochrane Database of Systematic Reviews CD012179. (https://doi.org/10.1002/14651858.CD012179)

Nnoaham KE, Hummelshoj L, Webster P, D’Hooghe T, De Cicco Nardone F, De Cicco Nardone C, Jenkinson C, Kennedy SH \& Zondervan KT 2011 Impact of endometriosis on quality of life and work productivity: a multicenter study across ten countries. Fertility and Sterility 96 366.e8-373.e8. (https://doi.org/10.1016/j. fertnstert.2011.05.090)

Noble S, Simpson R \& Bulun E $1996 a$ Aromatase expression in endometriosis. Journal of Clinical Endocrinology and Metabolism 450 174-179.

Noble LS, Simpson ER, Johns A \& Bulun SE 1996b Aromatase expression in endometriosis. Journal of Chnical Endocrinology and Metabolism $\mathbf{8 1}$ 174-179.

Noble LS, Takayama K, Zeitoun KM, Putman JM, Alan D, Hinshelwood MM, Agarwal VR, Zhao Y, Carr BR \& Bulun SE 1997 Prostaglandin E2 stimulates aromatase expression in endometriosisderived stromal cells. Journal of Clinical Endocrinology and Metabolism 82 600-606. (https://doi.org/10.1210/jcem.82.2.3783)

Pavone ME \& Bulun SE 2012 Aromatase inhibitors for the treatment of endometriosis: a review. Fertility and Sterility 98 1370-1379. (https:// doi.org/10.1016/j.fertnstert.2012.08.053)

Penning TM 2017 Aldo-Keto Reductase (AKR) 1C3 inhibitors: a patent review. Expert Opinion on Therapeutic Patents 3776 1-12. (https://doi. org/10.1080/13543776.2017.1379503)

Penning TM \& Byrns MC 2009 Steroid hormone transforming aldo-keto reductases and cancer. Annals of the New York Academy of Sciences 1155 33-34. (https://doi.org/10.1111/j.1749-6632.2009.03700.x)

Penning TM, Burczynski ME, Jez JM, Hung CF, Lin HK, Ma H, Moore M, Palackal N \& Ratnam K 2000 Human 3alpha-hydroxysteroid dehydrogenase isoforms (AKR1C1-AKR1C4) of the aldo-keto reductase superfamily: functional plasticity and tissue distribution reveals roles in the inactivation and formation of male and female sex hormones. Biochemical Journal 351 67-77. (https://doi. org/10.1042/0264-6021:3510067)

Piccinato CA, Neme RM, Torres N, Sanches LR, Derogis PBMC, Brudniewski HF, Rosa E Silva JC \& Ferriani RA 2016a Effects of steroid hormone on estrogen sulfotransferase and on steroid sulfatase expression in endometriosis tissue and stromal cells. Journal of Steroid Biochemistry and Molecular Biology 158 117-126. (https:// doi.org/10.1016/j.jsbmb.2015.12.025)

Piccinato CA, Neme RM, Torres N, Sanches LR, Derogis PBMC, Brudniewski HF, Rosa e Silva JC \& Ferriani RA $2016 b$ Increased expression of CYP1A1 and CYP1B1 in ovarian/peritoneal endometriotic lesions. Reproduction 151 683-692. (https://doi. org/10.1530/REP-15-0581)

Piccinato CA, Neme RM, Torres N, Silvério R, Pazzini VB, Rosa e Silva JC \& Ferriani RA 2016c Is cytochrome P450 3A4 regulated by menstrual cycle hormones in control endometrium and endometriosis? Molecular and Cellular Biochemistry 1-9. (https://doi.org/10.1007/ s11010-016-2899-3)

Platteeuw L \& D'Hooghe T 2014 Novel agents for the medical treatment of endometriosis. Current Opinion in Obstetrics and Gynecology 26 243-252. (https://doi.org/10.1097/GCO.0000000000000084) 
Plaza-Parrochia F, Poblete C, Gabler F, Carvajal R, Romero C, Valladares L \& Vega M 2015 Expression of steroid sulfated transporters and $3 \beta$-HSD activity in endometrium of women having polycystic ovary syndrome. Steroids 104 189-195. (https://doi. org/10.1016/j.steroids.2015.10.001)

Pohl O, Bestel E \& Gotteland JP 2014 Synergistic effects of E2MATE and norethindrone acetate on steroid sulfatase inhibition: a randomized phase i proof-of-principle clinical study in women of reproductive age. Reproductive Sciences 21 1256-1265. (https://doi. org/10.1177/1933719114522526)

Practice T \& Medicine R 2012 Endometriosis and infertility: a committee opinion. Fertility and Sterility 98 591-598. (https://doi.org/10.1016/j. fertnstert.2012.05.031)

Purohit A \& Foster PA 2012 Steroid sulfatase inhibitors for estrogen- and androgen-dependent cancers. Journal of Endocrinology 212 99-110. (https://doi.org/10.1530/JOE-11-0266)

Purohit A, Fusi L, Brosens J, Woo LWL, Potter BVL \& Reed MJ 2008 Inhibition of steroid sulphatase activity in endometriotic implants by 667 COUMATE: a potential new therapy. Scientific World Journal 8 1325-1327. (https://doi.org/10.1100/tsw.2008.164)

Rakhila H, Carli C, Daris M, Lemyre M, Leboeuf M \& Akoum A 2013 Identification of multiple and distinct defects in prostaglandin biosynthetic pathways in eutopic and ectopic endometrium of women with endometriosis. Fertility and Sterility 100. (https://doi. org/10.1016/j.fertnstert.2013.08.016)

Reed MJ, Purohit A, Woo LWL, Newman SP \& Potter BVL 2005 Steroid sulfatase: molecular biology, regulation, and inhibition. Endocrine Reviews 26 171-202. (https://doi.org/10.1210/er.2004-0003)

Rižner TL 2009 Estrogen metabolism and action in endometriosis. Molecular and Cellular Endocrinology 307 8-18. (https://doi. org/10.1016/j.mce.2009.03.022)

Rižner TL 2013 Estrogen biosynthesis, phase I and phase II metabolism, and action in endometrial cancer. Molecular and Cellular Endocrinology 381 124-139. (https://doi.org/10.1016/j.mce.2013.07.026)

Rižner TL 2016 The important roles of steroid sulfatase and sulfotransferases in gynecological diseases. Frontiers in Pharmacology $\mathbf{7}$ 1-16. (https://doi.org/10.3389/fphar.2016.00030)

Rižner TL, Thalhammer T \& Özvegy-Laczka C 2017 The importance of steroid uptake and intracrine action in endometrial and ovarian cancers. Frontiers in Pharmacology 8. (https://doi.org/10.3389/ fphar.2017.00346)

Roth M, Obaidat A \& Hagenbuch B 2012 OATPs, OATs and OCTs: the organic anion and cation transporters of the SLCO and SLC22A gene superfamilies. British Journal of Pharmacology 165 1260-1287. (https://doi.org/10.1111/j.1476-5381.2011.01724.x)

Rubin GL, Harrold AJ, Mills JA, Falany CN \& Coughtrie MWH 1999 Regulation of sulphotransferase expression in the endometrium during the menstrual cycle, by oral contraceptives and during early pregnancy. Molecular Human Reproduction 5 995-1002. (https://doi. $\operatorname{org} / 10.1093 /$ molehr/5.11.995)

Ruiz FX, Porté S, Gallego O, Moro A, Ardèvol A, Del Río-Espínola A, Rovira C, Farrés J \& Parés X 2011 Retinaldehyde is a substrate for human aldo-keto reductases of the 1C subfamily. Biochemical Journal 440 335-347. (https://doi.org/10.1042/BJ20111286)

Sapkota Y, Steinthorsdottir V, Morris AP, Fassbender A, Rahmioglu N, De Vivo I, Buring JE, Zhang F, Edwards TL, Jones S, et al. 2017 Meta-analysis identifies five novel loci associated with endometriosis highlighting key genes involved in hormone metabolism. Nature Communications 8 15539. (https://doi. org/10.1038/ncomms15539)

Secky L, Svoboda M, Klameth L, Bajna E, Hamilton G, Zeillinger R, Jäger W \& Thalhammer T 2013 The sulfatase pathway for estrogen formation: targets for the treatment and diagnosis of hormoneassociated tumors. Journal of Drug Delivery 2013 1-13. (https://doi. org/10.1155/2013/957605)
Shen L, Yang S, Huang W, Xu W, Wang Q, Song Y \& Liu Y 2013 MicroRNA23a and MicroRNA23b deregulation derepresses SF-1 and upregulates estrogen signaling in ovarian endometriosis. Journal of Clinical Endocrinology and Metabolism 98 1575-1582. (https://doi. org/10.1210/jc.2012-3010)

Signorile PG \& Baldi A 2010 Endometriosis: new concepts in the pathogenesis. International Journal of Biochemistry and Cell Biology $\mathbf{4 2}$ 778-780. (https://doi.org/10.1016/j.biocel.2010.03.008)

Simard J, Ricketts ML, Gingras S, Soucy P, Feltus FA \& Melner MH 2005 Molecular biology of the 3B-hydroxysteroid dehydrogenase/5-4 isomerase gene family. Endocrine Reviews 26 525-582. (https://doi. org/10.1210/er.2002-0050)

Sinreih M, Anko M, Kene NH, Kocbek V \& Rižner TL 2015 Expression of AKR1B1, AKR1C3 and other genes of prostaglandin F2 $\alpha$ biosynthesis and action in ovarian endometriosis tissue and in model cell lines. Chemico-Biological Interactions 234 320-331. (https://doi. org/10.1016/j.cbi.2014.11.009)

Smuc T, Pucelj MR, Sinkovec J, Husen B, Thole H \& Lanisnik Rizner T 2007 Expression analysis of the genes involved in estradiol and progesterone action in human ovarian endometriosis. Gynecological Endocrinology 23 105-111. (https://doi. org/10.1080/09513590601152219)

Šmuc T, Hevir N, Ribič-Pucelj M, Husen B, Thole H \& Rižner TL 2009 Disturbed estrogen and progesterone action in ovarian endometriosis. Molecular and Cellular Endocrinology 301 59-64. (https://doi.org/10.1016/j.mce.2008.07.020)

Soffientini U \& Graham A 2016 Intracellular cholesterol transport proteins: roles in health and disease. Clinical Science 130 1843-1859. (https://doi.org/10.1042/CS20160339)

Soucy P \& Van L-T 2000 Conversion of pregnenolone to DHEA by human. Molecular Endocrinology 3247 3243-3247.

Stanway SJ, Purohit A, Woo LWL, Sufi S, Vigushin D, Ward R, Wilson RH, Stanczyk FZ, Dobbs N, Kulinskaya E, et al. 2006 Phase I study of STX 64 (667 Coumate) in breast cancer patients: The first study of a steroid sulfatase inhibitor. Clinical Cancer Research 12 1585-1592. (https://doi.org/10.1158/10780432.CCR-05-1996)

Suganuma I, Mori T, Ito F, Tanaka Y, Sasaki A, Matsuo S, Kusuki I \& Kitawaki J 2014 Peroxisome proliferator-activated receptor gamma, coactivator 1alfa enhances local estrogen biosynthesis by stimulating aromatase activity in endometriosis. Journal of Clinical Endocrinology and Metabolism 99. (https://doi.org/10.1210/jc.2013-2525)

Sun HS, Hsiao KY, Hsu CC, Wu MH \& Tsai SJ 2003 Transactivation of steroidogenic acute regulatory protein in human endometriotic stromal cells is mediated by the prostaglandin EP2 receptor. Endocrinology 144 3934-3942. (https://doi.org/10.1210/en.20030289)

Szczepańska M, Wirstlein P, Skrzypczak J \& Jagodziński PP 2013 Polymorphic variants of CYP17 and CYP19A and risk of infertility in endometriosis. Acta Obstetricia et Gynecologica Scandinavica 92 1188-1193. (https://doi.org/10.1111/aogs.12210)

Tamaresis JS, Irwin JC, Goldfien GA, Rabban JT, Burney RO, Nezhat C, DePaolo L V. \& Giudice LC 2014 Molecular classification of endometriosis and disease stage using high-dimensional genomic data. Endocrinology 155 4986-4999. (https://doi.org/10.1210/en.20141490)

Tian Y, Kong B, Zhu W, Su S \& Kan Y 2009 Expression of steroidogenic factor 1 (SF-1) and steroidogenic acute regulatory protein (StAR) in endometriosis is associated with endometriosis severity. Journal of International Medical Research 1 1389-1395. (https://doi. org/10.1177/147323000903700513)

Tsai S, Wu MH, Lin C, Sun H \& Chen H 2001 Regulation of steroidogenic acute regulatory protein expression and progesterone production in endometriotic stromal cells. Journal of Clinical Endocrinology and Metabolism 86 5765-5773. 
Tseng L 1984 Estrogen synthesis in human endometrial epithelial glands and stromal cells. Journal of Steroid Biochemistry 20 877-881. (https:// doi.org/10.1016/0022-4731(84)90399-6)

Tsuchiya Y, Nakajima M \& Yokoi T 2005a Cytochrome P450-mediated metabolism of estrogens and its regulation in human. Cancer Letters 227 115-124. (https://doi.org/10.1016/j.canlet.2004.10.007)

Tsuchiya M, Nakao H, Katoh T, Sasaki H, Hiroshima M, Tanaka T, Matsunaga T, Hanaoka T, Tsugane S \& Ikenoue T 2005b Association between endometriosis and genetic polymorphisms of the estradiolsynthesizing enzyme genes HSD17B1 and CYP19. Human Reproduction 20 974-978. (https://doi.org/10.1093/humrep/deh726)

Urata Y, Osuga Y, Akiyama I, Nagai M, Izumi G, Takamura M, Hasegawa A, Harada M, Hirata T, Hirota Y, et al. 2013 Interleukin-4 and prostaglandin E2 synergistically up-regulate 3B-hydroxysteroid dehydrogenase type 2 in endometrioma stromal cells. Journal of Clinical Endocrinology and Metabolism 98 1583-1590. (https://doi. org/10.1210/jc.2012-3475)

Utsunomiya H 2001 The analyses of 17-hydroxysteroid dehydrogenase isozymes in human endometrial hyperplasia and carcinoma. Journal of Clinical Endocrinology and Metabolism 86 3436-3443. (https://doi. org/10.1210/jc.86.7.3436)

Utsunomiya H, Cheng Y-H, Lin Z, Reierstad S, Yin P, Attar E, Xue Q Imir G, Thung S, Trukhacheva E, et al. 2008 Upstream stimulatory factor-2 regulates steroidogenic factor-1 expression in endometriosis. Molecular Endocrinology 22 904-914. (https://doi.org/10.1210/ me.2006-0302)

Van LT 2013 Assessment of steroidogenesis and steroidogenic enzyme functions. Journal of Steroid Biochemistry and Molecular Biology 137 176-182. (https://doi.org/10.1016/j.jsbmb.2013.05.017)

Veillat V, Sengers V, Metz CN, Roger T, Leboeuf M, Mailloux J \& Akoum A 2012 Macrophage migration inhibitory factor is involved in a positive feedback loop increasing aromatase expression in endometriosis. American Journal of Pathology 181 917-927. (https:// doi.org/10.1016/j.ajpath.2012.05.018)

Vercellini P, Viganò P, Somigliana E \& Fedele L 2014 Endometriosis: pathogenesis and treatment. Nature Reviews 10 261-275. (https://doi. org/10.1038/nrendo.2013.255)

Vercellini P, Buggio L, Berlanda N, Barbara G, Somigliana E \& Bosari S 2016 Estrogen-progestins and progestins for the management of endometriosis. Fertility and Sterility 106 1552-1571.e2. (https://doi. org/10.1016/j.fertnstert.2016.10.022)

Vitonis AF, Baer HJ, Hankinson SE, Laufer MR \& Missmer SA 2010 A prospective study of body size during childhood and early adulthood and the incidence of endometriosis. Human Reproduction $\mathbf{2 5}$ 1325-1334. (https://doi.org/10.1093/humrep/deq039)

Xue Q, Lin Z, Cheng Y-H, Huang C-C, Marsh E, Yin P, Milad MP Confino E, Reierstad S, Innes J, et al. 2007 Promoter methylation regulates estrogen receptor 2 in human endometrium and endometriosis. Biology of Reproduction 77 681-687. (https://doi. org/10.1095/biolreprod.107.061804)

Yi K, Yang LY, Lan Z \& Xi MR 2016 The association between CYP19 polymorphism and endometriosis risk: a system review and metaanalysis. European Journal of Obstetrics and Gynecology and Reproductive Biology 199 42-48. (https://doi.org/10.1016/j.ejogrb.2016.01.010)

Zaichuk T, Ivancic D, Scholtens D, Schiller C \& Khan SA 2007 Tissuespecific transcripts of human steroid sulfatase are under control of estrogen signaling pathways in breast carcinoma. Journal of Steroid Biochemistry and Molecular Biology 105 76-84. (https://doi. org/10.1016/j.jsbmb.2006.12.101)

Zeitoun K, Takayama K, Michael MD \& Bulun SE 1999 Stimulation of aromatase $\mathrm{P} 450$ promoter (II) activity in endometriosis and its inhibition in endometrium are regulated by competitive binding of steroidogenic factor- 1 and chicken ovalbumin upstream promoter transcription factor to the same cis-acting elem. Molecular Endocrinology 13 239-253. (https://doi.org/10.1210/me.13.2.239)

Zelenko Z, Aghajanova L, Irwin JC \& Giudice LC 2012 Nuclear receptor, coregulator signaling, and chromatin remodeling pathways suggest involvement of the epigenome in the steroid hormone response of endometrium and abnormalities in endometriosis. Reproductive Sciences 19 152-162. (https://doi.org/10.1177/1933719111415546)

Zeng C, Xu JN, Zhou Y, Yang HX, Zhou YF \& Xue Q 2015 C-Jun NH2terminal kinase and p38 inhibition suppresses prostaglandin E2-stimulated aromatase and estrogen receptor levels in human endometriosis. Journal of Clinical Endocrinology and Metabolism 100 E1404-E1414. (https://doi.org/10.1210/jc.2015-2031)

Zhang H, Varmalova O, Vargas FM, Falany CN \& Leyh TS 1998 Sulfuryl transfer: the catalytic mechanism of human estrogen sulfotransferase. Journal of Biological Chemistry 273 17296. (https:// doi.org/10.1074/jbc.273.18.10888)

Zhang CY, Wang WQ, Chen J \& Lin SX 2015 Reductive 17betahydroxysteroid dehydrogenases which synthesize estradiol and inactivate dihydrotestosterone constitute major and concerted players in ER+ breast cancer cells. Journal of Steroid Biochemistry and Molecular Biology 150 24-34. (https://doi.org/10.1016/j. jsbmb.2014.09.017)

Zhao Y, Gong P, Chen Y, Nwachukwu JC, Srinivasan S, Ko C, Bagchi MK, Taylor RN, Korach KS, Nettles KW, et al. 2015 Dual suppression of estrogenic and inflammatory activities for targeting of endometriosis. Science Translational Medicine 7 271ra9. (https://doi.org/10.1126/ scitranslmed.3010626)

Zubrzycka A, Zubrzycki M, Janecka A \& Zubrzycka M 2015 New horizons in the etiopathogenesis and non-invasive diagnosis of endometriosis. Current Molecular Medicine 15 697-713. (https://doi. org/10.2174/1566524015666150921105218)

Received in final form 20 April 2018

Accepted 3 May 2018
๑) 2018 Society for Endocrinology Published by Bioscientifica Ltd. Printed in Great Britain 